\title{
Pembangunan Dashboard untuk Mendukung Analisis Kartu Rencana Studi dan Kartu Hasil Studi Mahasiswa
}

\author{
http://dx.doi.org/10.28932/jutisi.v7i1.3355 \\ Riwayat Artikel \\ Received: 30 Januari 2021 | Final Revision: 3 Maret 2021 | Accepted: 16 Maret 2021
}

\author{
Debora Syebat Nazir ${ }^{\bowtie 1}$, Gloria Virginia ${ }^{\# 2}$, Restyandito ${ }^{\# 3}$, Agata Filiana ${ }^{\# 4}$, Andhika Galuh Prabawati ${ }^{\# 5}$ \\ Informatika,Universitas Kristen Duta Wacana \\ Jl. Dr. Wahidin Sudiro Husodo no. 1-25, Yogyakarta \\ ${ }^{1}$ debora.syebateti. ukdw.ac.id \\ ${ }^{2}$ virginia@ti.ukdw.ac.id \\ ${ }^{3}$ ditodti.ukdw.ac.Id \\ ${ }^{4}$ afiliana@ti.ukdw.ac.id \\ ${ }^{5}$ andhika.galuhestaff.ukdw.ac.id
}

\begin{abstract}
Dashboard development to support the analysis of student study plan card and academic transcript using the Goal Directed design (GDD) method with 6 stages of research. The design results are then analyzed using the performance metric method. Performance metrics method is used to evaluate the user interface of the dashboard with $71 \%$ binary success. User Experience Questionnaire (UEQ) is also used to evaluate user experience showing scores of 1.96, 1.93, 1.77, 1.88 and 1.86 for attraction, stimulation, novelty, clarity and efficiency, respectively. These scores can be translated using the Comparison to Benchmark Scale table which shows good for both clarity and efficiency, and excellent for attraction, stimulation and novelty.
\end{abstract}

Keywords—Dashboard; GDD; KPI; Performance Metric.

\section{Pendahuluan}

Salah satu kegiatan penunjang akademik perguruan tinggi adalah proses registrasi mahasiswa. Melalui proses registrasi, mahasiswa mendapatkan KRS (Kartu Rencana Studi) dan KHS (Kartu Hasil Studi) sebagai laporan hasil kegiatan perkuliahan. Kegiatan registrasi perguruan tinggi dikelola oleh bagian akademik masing-masing instansi contohnya Kaprodi dan Staff PPA. Selain itu, setiap Instansi perguruan tinggi atau program studi memiliki beberapa poin penilaian/indikator untuk mencapai sebuah lingkungan kerja yang baik. Setiap semester, Kaprodi selalu membuat laporan akademik. Banyaknya data menyebabkan Kaprodi kesulitan dalam membaca dan menganalisis data tersebut. Disamping itu, untuk menganalisis data mahasiswa per semester dibutuhkan waktu yang lama. Kesalahan manusia karena kelelahan, kesalahan penulisan/pengetikan dalam pengelolahan data juga merupakan faktor yang dapat mempengaruhi keakuratan data.

Salah satu bentuk visualisasi data untuk permasalahan diatas adalah dengan dashboard. Menurut [1], dashboard dapat digunakan sebagai sarana dalam membantu pimpinan perguruan tinggi untuk memonitoring dan mengevaluasi kinerja organisasinya. Dashboard menyajikan data dalam bentuk antarmuka visual secara sekilas dalam satu layar, sehingga data dapat dianalisa dengan lebih efektif dan efisien. Dari penelitian tersebut menunjukan bahwa total dari ratarata seluruh variabel karakteristik dashboard mengalami kenaikan $11 \%$, yang berarti bahwa dashboard memenuhi kebutuhan dari pengguna dalam hal mengetahui ketercapaian kinerja.

Oleh sebab itu, Kaprodi memerlukan dashboard sebagai alat yang dapat digunakan untuk menampilkan data guna menganalisis data secara berkala setiap semesternya melalui KPI yang telah ditetapkan. Dashboard tersebut diharapkan mampu menampilkan KPI dan mengolah data secara otomatis dan akurat dalam waktu yang singkat. Sehingga, Kaprodi dapat menganalisis baik buruknya data dalam sekali lihat. Dashboard yang dibangun bertujuan untuk menampilkan KPI yang dibuat berdasarkan penelitian tentang Pengembangan Key Performance Indicator untuk Manajemen Pendidikan Tinggi yang dilakukan oleh Andhika Galuh P (2019) dengan sumber data KRS \& KHS mahasiswa. Penelitian tersebut menjelaskan cara menganalisis KRS dan KHS dengan FGD internal pihak kampus serta mengadopsi Borang Akreditasi Perguruan Tinggi dengan studi kasus program studi Informatika UKDW. 


\section{TINJAUAN PUSTAKA}

\section{A. Tinjauan Pustaka}

Penelitian terdahulu oleh [2] dengan judul Rekomendasi User interface untuk Aplikasi Mobile Selesi Mahasiswa Baru (SBM) Telkom Menggunakan Metode Goal Directed Design (GDD) merupakan aplikasi yang mempermudah calon mahasiswa baru untuk mendapatkan informasi berkaitan dengan seleksi mahasiswa baru. Penelitian ini melibatkan 10 variabel usability QUIM dimana dalam satu variable tersebut terdapat satu atau lebih pertanyaan yang mewakili variabel tersebut. Sebelum pertanyaan diberikan kepada pengguna, pengujian dilakukan guna mengetahui validitas dan reabilitas dari setiap pertanyaan tersebut. Hasil dari pengujian tingkat usability didapatkan nilai $87 \%$, sehingga prototype yang dirancang masuk ke dalam interval "sangat baik".

Dalam penelitian lain tentang perancangan user experience aplikasi Computer Assisted Test (CAT) selain menggunakan Metode Goal-directed design untuk mencapai tujuan utama yang ingin dicapai, pada tahap requirement definition digunakan metode pendukung lainnya, yaitu Hirarchical Task Analysis (HTA) untuk mengidentifikasi task apa saja yang dibutuhkan dalam mencapai goals tersebut. Selain itu, dilakukan evaluasi secara kuantitatif dengan menggunakan kuesioner User Experience Questionnaire (UEQ). Sebanyak 20 reponden untuk tipe pengguna peserta ujian dan 7 responden untuk tipe pengguna panitia ujian. Pelaksanaan kuisioner UEQ memberikan hasil kategori excellent pada skala attractiveness yaitu dengan rata-rata 1.96. Efficiency dengan rata-rata 1.96 , stimulation dengan rata-rata 1.93 , dan novelty dengan rata-rata 2.08 serta mendapatkan kategori good pada skala perspicuity dengan rata-rata 1.79 dan dependability dengan rata-rata 1.74 untuk tampilan peserta ujian. Sedangkan pada tampilan untuk panitia ujian menghasilkan kategori excellent pada keenam skala dari UEQ dimana pada skala attractiveness dengan rata-rata 2.02, skala perspicuity dengan rata-rata 1.93 efficiency dengan rata-rata 2.04, dan dependability dengan rata-rata 1.96 , stimulation dengan rata-rata 2.00 , dan novelty dengan ratarata 1.93 [3].

Metode Goal-Directed design digunakan dalam penelitian lain oleh [4]. Terdapat 6 tahap dalam GDD, yaitu Research, Modeling, Requirements, Framework, Refinement dan Support. Metode GDD dibantu dengan prinsip dalam desain perancangan antarmuka yakni 8 Golden Rules Interface Design, selain itu, diterapkan teknik card sorting dan wireframe untuk mendapatkan perancangan struktur informasi yang lebih baik. Dukungan lainnya ialah dilakukan pengujian dengan menerapkakn user testing dan menggunakan Standardized User Experience Percentile Rank Questionare (SUPR-Q) untuk mendapatkan feedback penilaian terkait aspek usability, credibility, appearance dan loyalty. Ditemukan indikator permasalahan dalam situs web daqumalang.or.id seperti pemilihan dan penataan gambar maupun tulisan yang kurang sesuai. Masih minimnya informasi yang disajikan, navigasi halaman yang tidak dijelaskan pada tampilan dan fitur tersebut. Hasil kuesioner SUPR-Q menunjukan aspek penilaian usability, creadibility, appearance dan loyalty dengan keseluruhan aspek bernilai $74,57 \%$ (kategori C) yakni bernilai baik dan dapat diterima (acceptable) berdasarkan skala konversi usability.

Penelitian yang akan dilakukan berfokus pada pembuatan dashboard dengan menggunakan metode GDD yaitu tahap research, modelling, requirement definition, design framework, design refinement, dan development support. HTA merupakan suatu proses menguraikan tugas menjadi subtugas dimana fungsi tugas utama tersebut digunakan untuk mencapai tujuan pengguna. Analisis tugas dapat berupa hal-hal yang pengguna kerjakan, hal-hal yang pengguna kenai pekerjaan, dan hal-hal yang perlu pengguna ketahui [5]. Selain itu, untuk menilai user interface pada dashboard akan digunakan metode Performance Metrics dengan 4 tahap pengujian yaitu task on time, task success, error, dan efficiency. Penilaian user experience digunakan metode evaluasi UEQ dengan merujuk pada jurnal [6]-[8].

\section{B. Visualisasi Data}

Data bukan sekedar angka mentah yang dilihat oleh mata. Data berupa angka yang dapat divisualisasikan menggunakan teknik visualisasi data. Visualisasi data memanfaatkan kemampuan sistem visual manusia untuk melihat relasi dan tren yang ada. Terlalu banyak informasi yang masuk, membuat manusia susah dalam memahami data tersebut. Hal yang diperhatikan ketika ingin memvisualisasikan data adalah melihat pola yang akan direpresentasikan, selain itu timeline atau kapan kondisi tersebut terjadi, dan hubungan dimana data tersebut memiliki makna untuk responden atau tidak. Visualisasi data merupakan salah satu cara menampilkan dan juga mempengaruhi. Terdapat 3 hal yang perlu diperhatikan dalam memvisualisasikan data, yang pertama adalah variabilitas.

Pertama adalah variabilitas yang menunjukkan pola di setiap aktivitas, kecenderungan, maupun perputaran pada data itu sendiri. Kedua adalah ketidakpastian, ketidakpastian adalah perkiraan. Hal ini memperhatikan confident level dan confident interval. Terakhir adalah konteks, konteks sangat membantu pembaca dalam memaknai data tersebut. Tanpa konteks, data, dan visualisasinya menjadi tidak berguna, sehingga kita perlu mengetahui $5 \mathrm{~W} 1 \mathrm{H}$ dalam menentukan konteks. Beberapa komponen yang dapat diperhatikan saat mevisualisasikan data, contohnya visual cues meliputi posisi, panjang, sudut, arah, bentuk, area, volume, dan warna [9].

\section{Dashboard}

Dashboard dirancang untuk menunjukkan informasi kunci yang dibutuhkan oleh pengguna untuk membantu memantau barang-barang atau hal-hal yang menjadi tanggung jawab pengguna tersebut dan kemudian pengguna tersebut dapat 
dengan cepat menemukan masalah dan mengambil tindakan untuk membantu meningkatkan kinerja organisasi mereka. Terdapat 3 jenis dashboard [10], yaitu:

- Strategic dashboard, mendukung adanya penyelarasan organisasi dengan tujuan yang ingin dicapai.

- Tactical dashboard, memungkinkan adanya evaluasi terhadap progres sebuah organisasi dalam mencapai sebuah tujuan.

- Operational dashboard, memantau aktivitas bisnis sebuah perusahaan secara lebih spesifik.

Gambar 1 merupakan proses implementasi dashboard dari rencana pembangunan dashboard hingga tahap deploy and intergrate dashboard.

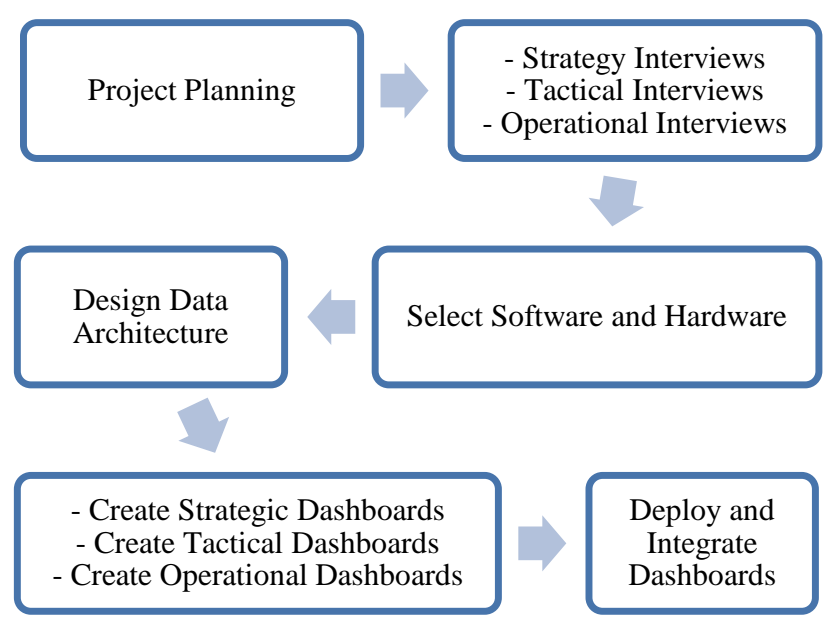

Gambar 1. Proses Implementasi Dashboard

\section{Kurikulum}

Masing-masing prodi memiliki tugas untuk menyusun dan memperbaharui kurikulum yang menjadi acuan untuk rencana pembelajaran tiap semester. Rencana pembelajaran semester (RPS) mengatur tentang nama program studi, nama dan kode mata kuliah, semester, sks, nama dosen pengampu, kriteria, indikator, dan masih banyak lagi lainnya. Beberapa regulasi akademik program studi Informatika Universitas Kristen Duta Wacana yang disusun dalam Panduan Akademik Kurikulum 2017 yang diambil secara verbatim adalah sebagai berikut (Virginia, dkk., 2017):

1) Status Mahasiswa: Mahasiswa Prodi TI UKDW dikategorikan berdasarkan status mahasiswanya dengan mengacu pada Peraturan Akademik Universitas di UKDW (QADW-1000-PA-09.04.003) yaitu mahasiswa aktif, mahasiswa tidak aktif, mahasiswa cuti studi, mahasiswa terkena skorsing, mahasiswa undur diri dan mahasiswa meninggal dunia.

2) Perwalian: Dosen tidak hanya memberikan pengajaran akan tetapi dosen dapat memberikan konsultasi baik bersifat akademik maupun non akademik kepada mahasiswa guna menyelesaikan studi tepat waktu dan selanjutnya disebut dosen wali. Dosen wali adalah seorang dosen yang telah memiliki pengalaman mengajar sekurangkurangnya 1 tahun (2 semester) dan ditetapkan oleh Ketua Program Studi.

3) Predikat Kelulusan: Predikat kelulusan mahasiswa Prodi Informatika UKDW diberikan dengan kriteria seperti Tabel I.

TABEL I

PREDIKAT KELULUSAN MAHASISWA

\begin{tabular}{|c|c|}
\hline IPK & Predikat \\
\hline $2,50 \leq \mathrm{IPK} \leq 2,75$ & Baik \\
\hline $2,75<\mathrm{IPK} \leq 3,00$ & Memuaskan \\
\hline $3,00<\mathrm{IPK} \leq 3,50$ & Sangat Memuaskan \\
\hline$\geq 3,50$ & Pujian \\
\hline
\end{tabular}

4) Peraturan Pengambilan sks: Total sks ditentukan berdasarkan IPK dan IPS yang didapatkan sebelumnya (terakhir), pengambilan sks ditampilkan pada Tabel II.

TABEL II

PENGAMBILAN SKS

\begin{tabular}{|c|c|c|c|c|c|c|c|c|c|c|}
\hline IPS &  & $\begin{array}{l}\hat{b} \\
\text { ले } \\
\text { । } \\
\text { ले }\end{array}$ & $\begin{array}{l}\text { ते } \\
\text { m } \\
\text { ह } \\
\text { ह }\end{array}$ & $\begin{array}{l}\text { बे } \\
\text { ते } \\
\text { i } \\
\text { กi }\end{array}$ & $\begin{array}{l}\hat{\sigma} \\
\text { ì } \\
1 \\
\text { ले } \\
\text { N }\end{array}$ & 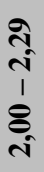 & $\begin{array}{l}\stackrel{2}{\sigma} \\
\stackrel{2}{1} \\
\stackrel{2}{=}\end{array}$ & 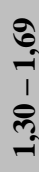 & 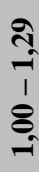 & $\begin{array}{l}\hat{\sigma} \\
\hat{\theta} \\
1 \\
\hat{8} \\
\hat{\theta}\end{array}$ \\
\hline $\begin{array}{c}3,70- \\
4,00\end{array}$ & 24 & $\begin{array}{l}2 \\
4\end{array}$ & $\begin{array}{l}2 \\
4\end{array}$ & $\begin{array}{l}2 \\
4\end{array}$ & $\begin{array}{l}2 \\
4\end{array}$ & $\begin{array}{l}2 \\
4\end{array}$ & $\begin{array}{l}2 \\
4\end{array}$ & $\begin{array}{l}2 \\
4\end{array}$ & $\begin{array}{l}2 \\
4\end{array}$ & $\begin{array}{l}2 \\
4\end{array}$ \\
\hline $\begin{array}{c}3,30- \\
3,69\end{array}$ & 24 & $\begin{array}{l}2 \\
4 \\
\end{array}$ & $\begin{array}{l}2 \\
4\end{array}$ & $\begin{array}{l}2 \\
4 \\
\end{array}$ & $\begin{array}{l}2 \\
4\end{array}$ & $\begin{array}{l}2 \\
4 \\
\end{array}$ & $\begin{array}{l}2 \\
4 \\
\end{array}$ & $\begin{array}{l}2 \\
4 \\
\end{array}$ & $\begin{array}{l}2 \\
4 \\
\end{array}$ & $\begin{array}{l}2 \\
3\end{array}$ \\
\hline $\begin{array}{c}3,00- \\
3,29 \\
\end{array}$ & 24 & $\begin{array}{l}2 \\
4 \\
\end{array}$ & $\begin{array}{l}2 \\
4 \\
\end{array}$ & $\begin{array}{l}2 \\
4 \\
\end{array}$ & $\begin{array}{l}2 \\
4 \\
\end{array}$ & $\begin{array}{l}2 \\
4 \\
\end{array}$ & $\begin{array}{l}2 \\
4 \\
\end{array}$ & $\begin{array}{l}2 \\
4 \\
\end{array}$ & $\begin{array}{l}2 \\
3 \\
\end{array}$ & $\begin{array}{l}2 \\
2 \\
\end{array}$ \\
\hline $\begin{array}{c}2,70- \\
2,99\end{array}$ & 24 & $\begin{array}{l}2 \\
4\end{array}$ & $\begin{array}{l}2 \\
4\end{array}$ & $\begin{array}{l}2 \\
4\end{array}$ & $\begin{array}{l}2 \\
4\end{array}$ & $\begin{array}{l}2 \\
4\end{array}$ & $\begin{array}{l}2 \\
4\end{array}$ & $\begin{array}{l}2 \\
3\end{array}$ & $\begin{array}{l}2 \\
2\end{array}$ & $\begin{array}{l}2 \\
1\end{array}$ \\
\hline $\begin{array}{c}2,30- \\
2,69\end{array}$ & 24 & $\begin{array}{l}2 \\
4\end{array}$ & $\begin{array}{l}2 \\
4\end{array}$ & $\begin{array}{l}2 \\
4\end{array}$ & $\begin{array}{l}2 \\
4\end{array}$ & $\begin{array}{l}2 \\
4\end{array}$ & $\begin{array}{l}2 \\
3\end{array}$ & $\begin{array}{l}2 \\
2\end{array}$ & $\begin{array}{l}2 \\
1\end{array}$ & $\begin{array}{l}2 \\
0\end{array}$ \\
\hline $\begin{array}{c}2,00- \\
2,29\end{array}$ & 24 & $\begin{array}{l}2 \\
4\end{array}$ & $\begin{array}{l}2 \\
4\end{array}$ & $\begin{array}{l}2 \\
4\end{array}$ & $\begin{array}{l}2 \\
4\end{array}$ & $\begin{array}{l}2 \\
3\end{array}$ & $\begin{array}{l}2 \\
2\end{array}$ & $\begin{array}{l}2 \\
1\end{array}$ & $\begin{array}{l}2 \\
0\end{array}$ & $\begin{array}{l}1 \\
9\end{array}$ \\
\hline $\begin{array}{c}1,70- \\
1,99\end{array}$ & 24 & $\begin{array}{l}2 \\
4\end{array}$ & $\begin{array}{l}2 \\
4\end{array}$ & $\begin{array}{l}2 \\
4\end{array}$ & $\begin{array}{l}2 \\
3\end{array}$ & $\begin{array}{l}2 \\
2\end{array}$ & $\begin{array}{l}2 \\
1\end{array}$ & $\begin{array}{l}2 \\
0\end{array}$ & $\begin{array}{l}1 \\
9\end{array}$ & $\begin{array}{l}1 \\
8\end{array}$ \\
\hline $\begin{array}{c}1,30- \\
1,69 \\
\end{array}$ & 24 & $\begin{array}{l}2 \\
4 \\
\end{array}$ & $\begin{array}{l}2 \\
4\end{array}$ & $\begin{array}{l}2 \\
3 \\
\end{array}$ & $\begin{array}{l}2 \\
2 \\
\end{array}$ & $\begin{array}{l}2 \\
1 \\
\end{array}$ & $\begin{array}{l}2 \\
0 \\
\end{array}$ & $\begin{array}{l}1 \\
9 \\
\end{array}$ & $\begin{array}{l}1 \\
8 \\
\end{array}$ & $\begin{array}{l}1 \\
7 \\
\end{array}$ \\
\hline $\begin{array}{c}1,00- \\
1,29\end{array}$ & 24 & $\begin{array}{l}2 \\
4\end{array}$ & $\begin{array}{l}2 \\
3\end{array}$ & $\begin{array}{l}2 \\
2\end{array}$ & $\begin{array}{l}2 \\
1\end{array}$ & $\begin{array}{l}2 \\
0\end{array}$ & $\begin{array}{l}1 \\
9\end{array}$ & $\begin{array}{l}1 \\
8\end{array}$ & $\begin{array}{l}1 \\
7\end{array}$ & $\begin{array}{l}1 \\
6\end{array}$ \\
\hline $\begin{array}{c}0,00- \\
0,99\end{array}$ & 24 & $\begin{array}{l}2 \\
3\end{array}$ & $\begin{array}{l}2 \\
2\end{array}$ & $\begin{array}{l}2 \\
1\end{array}$ & $\begin{array}{l}2 \\
0\end{array}$ & $\begin{array}{l}1 \\
9\end{array}$ & $\begin{array}{l}1 \\
8 \\
\end{array}$ & $\begin{array}{l}1 \\
7\end{array}$ & $\begin{array}{l}1 \\
6 \\
\end{array}$ & $\begin{array}{l}1 \\
5\end{array}$ \\
\hline
\end{tabular}

5) Kategori Penilaian: Berdasarkan SK Dekan FTI UKDW (2015) elemen evaluasi studi dinyatakan dalam bentuk kuantitatif dengan rentang nilai 0-100 yang ditunjukan lebih jelas melalui Tabel III. 
TABEL III

PREDIKAT KELULUSAN MAHASISWA

\begin{tabular}{|c|c|c|}
\hline Nilai Angka & Nilai Huruf & Bobot Nilai \\
\hline Nilai $\geq 85$ & A & 4,00 \\
\hline $80 \leq$ Nilai $<85$ & A- & 3,70 \\
\hline $75 \leq$ Nilai $<80$ & B + & 3,30 \\
\hline $70 \leq$ Nilai $<75$ & B & 3,00 \\
\hline $65 \leq$ Nilai $<70$ & B- & 2,70 \\
\hline $60 \leq$ Nilai $<65$ & C + & 2,30 \\
\hline $55 \leq$ Nilai $<60$ & C & 2,00 \\
\hline $45 \leq$ Nilai $<55$ & D & 1,00 \\
\hline Nilai $<45$ & E & 0,00 \\
\hline
\end{tabular}

6) Key Performance Indicator: KPI adalah seperangkat ukuran yang berfokus pada aspek-aspek kinerja organisasi untuk mencapai keberhasilan organisasi saat ini dan masa depan. Sangat sedikit organisasi yang benar-benar memantau KPI, hal ini dikarenakan stakeholder terdampak kurang mengekplorasi apa itu sebenarnya KPI [11]. Terdapat beberapa hal yang perlu diperhatikan dalam membangun KPI yaitu:

- Indikator adalah kondisi yang digunakan untuk membantu Dekanat dalam membuat penilaian ringkas terhadap aspek yang menunjang penilaian.

- Nilai Target adalah nilai sasaran atau ukuran yang ingin dicapai dalam sebuah organisasi. Nilai target ditentukan oleh Dekanat ataupun pihak-pihak yang bertanggung jawab dalam menentukan standar dalam perusahan.

- Nilai Batas adalah sebuah pemisah yang membagi antara nilai minimal dan nilai maksimal. Batas nilai yang ditentukan masing-masing organisasi berbedabeda. Hal ini dikarenakan target yang dicapai suatu perusahaan juga berbeda-beda.

\section{Metodologi PENELITIAN}

\section{A. Tahapan Penelitian}

Gambar 2 menampilkan bagan penelitian yang digunakan. Tahap penelitian di mulai dari mengidentifikasi permasalahan yang terjadi di Prodi Informatika Univeristas Kristen Duta Wacana, yang kemudian dilakukan studi literatur untuk meninjau metode apa yang tepat diterapkan. Dalam kasus ini menggunakan Metode Goal-Directed design dengan 6 tahap penelitian yaitu tahap research, modelling, requirement definition, design framework, design refinement, dan development support. Pada tahap design framework digunakan metode tambahan untuk menganalisis kebutuhan pengguna yaitu menggunakan metode HTA. Pada tahap development digunakan metode tambahan untuk mengetahui efektivitas dashboard yaitu menggunakan metode Performance Metric, sedangkan untuk mengevaluasi dashboard yang telah terbangun digunakan tools tambahan yaitu UEQ. Setelah di evaluasi maka akan didapatkan skor user experience pengguna dalam menggunakan dashboard. Hasil evaluasi digunakan untuk modifikasi, bagian mana yang masih rumit dipahami oleh pengguna.



Gambar 2. Diagram Alur Tahapan Penelitian

Berikut adalah penjelasan setiap tahap dalam metode Goal Directed design :

1) Research: Pada tahap ini dilakukan wawancara terhadap stakeholder yang secara langsung menggunakan, mengolah dan mengevaluasi data. Responden terdiri dari 2 orang yang paham dengan data yang digunakan, yaitu Kaprodi dan Staff PPA program studi Informatika. Wawancara dilakukan di Fakultas Teknologi Informasi pada jam kerja. Adapun pertanyaan dan hasil jawaban wawancara responden dijabarkan pada Tabel IV.

TABEL IV

HASIL WAWANCARA (RESEARCH)

\begin{tabular}{|l|c|}
\hline \multicolumn{1}{|c|}{ Topik Pertanyaan } & \multicolumn{1}{c|}{ Hasil Jawaban } \\
\hline $\begin{array}{l}\text { Context Product: } \\
\text { Kapan, mengapa dan } \\
\text { bagaimana produk } \\
\text { akan digunakan? }\end{array}$ & $\begin{array}{c}\text { Kapan: Setiap satu semester sekali } \\
\text { diakses } \\
\text { Mengapa: Dashboard akan digunakan } \\
\text { untuk laporan evaluasi dekanat } \\
\text { (laporan WD 1 Informatika) }\end{array}$ \\
\hline
\end{tabular}




\begin{tabular}{|c|c|}
\hline Topik Pertanyaan & Hasil Jawaban \\
\hline & $\begin{array}{l}\text { Bagaimana: Dashboard akan menjadi } \\
\text { bahan pertimbangan Kaprodi dalam } \\
\text { mengevaluasi setiap indikator yang } \\
\text { dijadikan acuan. }\end{array}$ \\
\hline $\begin{array}{l}\text { User Perspective: Apa } \\
\text { yang perlu diketahui } \\
\text { pengguna untuk } \\
\text { melakukan } \\
\text { pekerjaannya? }\end{array}$ & $\begin{array}{l}\text { Perencanaan untuk meningkatkan } \\
\text { performa prodi melalui Indikator } \\
\text { pendukung evaluasi, sehingga prodi } \\
\text { dapat dengan mudah menentukan } \\
\text { sikap. }\end{array}$ \\
\hline $\begin{array}{l}\text { Current Tasks and } \\
\text { Activities: Tugas dan } \\
\text { aktivitas saat ini, baik } \\
\text { yang harus dipenuhi } \\
\text { oleh produk saat ini } \\
\text { maupun untuk } \\
\text { melakukan } \\
\text { pekerjaannya? }\end{array}$ & $\begin{array}{l}\text { Mengolah data yang diambil dari web } \\
\text { starmik, lalu disesuaikan dengan } \\
\text { format evaluasi untuk dianalisis oleh } \\
\text { prodi (misal rekam jejak mahasiswa) } \\
\text { melalui rumus-rumus di excel, serta } \\
\text { dikelompokkan berdasarkan angkatan. }\end{array}$ \\
\hline $\begin{array}{l}\text { Goals: Tujuan untuk } \\
\text { menggunakan produk? }\end{array}$ & $\begin{array}{l}\text { Dashboard diharapkan mampu } \\
\text { membantu Kaprodi dalam } \\
\text { mempertimbangkan pengambilan } \\
\text { keputusan terbaik. Selain itu, untuk } \\
\text { mempermudah dalam melakukan } \\
\text { pelaporan evaluasi prodi. }\end{array}$ \\
\hline $\begin{array}{l}\text { Mental model: } \\
\text { Bagaimana pengguna } \\
\text { berpikir tentang } \\
\text { pekerjaan dan } \\
\text { aktivitas mereka } \\
\text { (asumsi, strategi, cara } \\
\text { pandang \& dasar } \\
\text { pemikiran), serta } \\
\text { harapan apa yang } \\
\text { dimiliki pengguna } \\
\text { tentang produk? }\end{array}$ & $\begin{array}{l}\text { Mempersingkat waktu yang } \\
\text { digunakan untuk menganalisis data. } \\
\text { Menghindari kerusakan pada } \\
\text { dokumen fisik serta kerusakan file. } \\
\text { Dalam sekali lihat, Kaprodi mampu } \\
\text { menarik kesimpulan dalam tiap } \\
\text { indikator (baik/buruk). Data lebih } \\
\text { akurat, lebih informatif, serta } \\
\text { mempermudah dalam evaluasi prodi. }\end{array}$ \\
\hline $\begin{array}{l}\text { Problem: Masalah saat } \\
\text { ini? }\end{array}$ & $\begin{array}{l}\text { Web starmik saat ini kurang cukup } \\
\text { untuk evaluasi prodi, karena beberapa } \\
\text { data dianggap masih inkonsisten. } \\
\text { Contohnya data mahasiswa undur diri } \\
\text { pada tahun } 2015 / 2016 \text { karena web } \\
\text { belum di update mahasiswa dianggap } \\
\text { aktif pada tahun ajaran tersebut. } \\
\text { Selain itu, dalam web tidak terdapat } \\
\text { rata-rata ipk persemester perangkatan, } \\
\text { sehingga data perlu diolah lagi. Status } \\
\text { mahasiswa, terlalu banyak pilihan } \\
\text { menu, contohnya mahasiswa aktif } \\
\text { akan tetapi ada tab pilihan aktif } \\
\text { regular, aktif, aktif studi. }\end{array}$ \\
\hline
\end{tabular}

2) Modeling: Pada tahap ini tidak dihasilkan persona pengguna. Persona merupakan alat desain yang berisi deskripsi singkat pengguna website, contohnya tujuan penggunaan, kebiasaan pengguna, kesulitan yang dihadapi, kebutuhan website yang diinginkan [10]. Persona tidak digunakan karena target responden yang dibutuhkan telah jelas ditentukan yaitu Kaprodi dan Staff PPA Informatika UKDW.
3) User Requirement: Daftar kebutuhan dashboard meliputi 9 KPI yang dijabarkan pada Tabel V. Dashboard yang dibangun bertujuan untuk menampilkan KPI yang dibuat berdasarkan penelitian [12] dengan sumber data KRS \& KHS mahasiswa. Penelitian tersebut membuat KPI dengan mengadopsi Borang Akreditasi Perguruan Tinggi dengan studi kasus program studi Informatika UKDW.

TABEL V

KEBUTUHAN DASHBOARD

\begin{tabular}{|c|c|c|}
\hline No & Kategori & Indikator KPI \\
\hline \multirow{3}{*}{1} & \multirow{3}{*}{$\begin{array}{l}\text { Indikator } \\
\text { Dosen }\end{array}$} & $\begin{array}{l}\text { Rata-rata banyaknya mahasiswa per } \\
\text { dosen pembimbing akademik per } \\
\text { semester. }\end{array}$ \\
\hline & & $\begin{array}{l}\text { Rata-rata beban mengajar dosen per } \\
\text { semester. }\end{array}$ \\
\hline & & $\begin{array}{l}\text { Rata-rata IPK Dosen di setiap } \\
\text { semester. }\end{array}$ \\
\hline \multirow{4}{*}{2} & \multirow{4}{*}{$\begin{array}{l}\text { Indikator } \\
\text { Registrasi }\end{array}$} & $\begin{array}{l}\text { Rata-rata jumlah mata kuliah yang } \\
\text { ditawarkan per semester. }\end{array}$ \\
\hline & & $\begin{array}{l}\text { Rata-rata kapasitas kelas disetiap } \\
\text { mata kuliah yang ditawarkan. }\end{array}$ \\
\hline & & $\begin{array}{l}\text { Prosentase mahasiswa yang DO } \\
\text { atau UD. }\end{array}$ \\
\hline & & Rasio dosen: Mahasiswa (RMD). \\
\hline \multirow{2}{*}{3} & \multirow{2}{*}{$\begin{array}{l}\text { Indikator } \\
\text { KRS \& KHS }\end{array}$} & $\begin{array}{l}\text { Rata-rata pengambilan mata kuliah } \\
\text { (sks) mahasiswa di setiap angkatan. }\end{array}$ \\
\hline & & $\begin{array}{l}\text { Rata-rata IPK semua mahasiswa } \\
\text { prodi Informatika. }\end{array}$ \\
\hline 4 & Detail Dosen & $\begin{array}{l}\text { Detail berisi semua chart indikator } \\
\text { yang terdapat pada } \mathrm{H} 01 \text {. }\end{array}$ \\
\hline 5 & $\begin{array}{c}\text { Detail } \\
\text { Registrasi }\end{array}$ & $\begin{array}{l}\text { Detail berisi semua chart indikator } \\
\text { yang terdapat pada } \mathrm{H} 02 \text {. }\end{array}$ \\
\hline 6 & $\begin{array}{c}\text { Detail KRS \& } \\
\text { KHS }\end{array}$ & $\begin{array}{l}\text { Detail berisi semua chart indikator } \\
\text { yang terdapat pada } \mathrm{H} 03 \text {. }\end{array}$ \\
\hline 7 & Metriks Dosen & $\begin{array}{l}\text { Metriks berisi semua report yang } \\
\text { terdapat pada D } 01 \text {. }\end{array}$ \\
\hline 8 & $\begin{array}{c}\text { Metriks } \\
\text { Registrasi } \\
\end{array}$ & $\begin{array}{l}\text { Metriks berisi semua report yang } \\
\text { terdapat pada D } 02 \text {. }\end{array}$ \\
\hline 9 & $\begin{array}{l}\text { Metriks KRS } \\
\text { \& KHS }\end{array}$ & $\begin{array}{l}\text { Metriks berisi semua report yang } \\
\text { terdapat pada D } 03 \text {. }\end{array}$ \\
\hline
\end{tabular}

4) Framework: Pada tahap framework, dibuat konsep produk secara keseluruhan dari hasil tahap research untuk dijadikan perancangan. Perancangan tersebut akan menggunakan alat visual untuk menghasilkan bagian-bagian yang sesuai dengan skenario konteks. Pada tahap ini akan terlihat struktur dan desain hasil dari wawancara [11]. Fokus utama HTA adalah penggunaan teks dan diagram dalam menunjukan hirarki dan perencanan untuk menjelaskan urutan tugas. Sebagai contoh deskripsi tekstual HTA dalam rangka menampilkan Dashboard KRS \& KHS adalah sebagai berikut:

0. Menampilkan Dashboard KRS dan KHS Mahasiswa

1. Menentukan Grafik KPI KRS \& KHS

2. Mengelompokkan KPI

2.1. Menentukan Kelompok/Kategori Dosen 
2.1.1. Menampilkan KPI rerata mahasiswa per dosen pembimbing akademik

2.1.2. Menampilkan KPI rerata beban mengajar dosen

2.1.3. Menampilkan KPI rerata IPK dosen

2.2. Menentukan Kelompok/Kategori Registrasi

2.2.1. Menampilkan KPI rerata mata kuliah yang diselenggarakan

2.2.2. Menampilkan KPI rerata peserta mata kuliah

2.2.3. Menampilkan KPI persentase status mahasiswa

2.2.4. Menampilkan KPI rasio dosen : mahasiswa

2.3. Menentukakan Kelompok/kategori KRS\&KHS

2.3.1. Menampilkan KPI rerata pengambilan sks

2.3.2. Menampilkan KPI rerata IPK semua mahasiswa prodi Informatika

Setelah dijabarkan melalui deskripsi tekstual dashboard, kemudian digambarkan menggunakan diagram untuk melihat lebih jelas tugas dan sub tugas dari dashboard yang dibangun yang digambarkan pada Gambar 3.

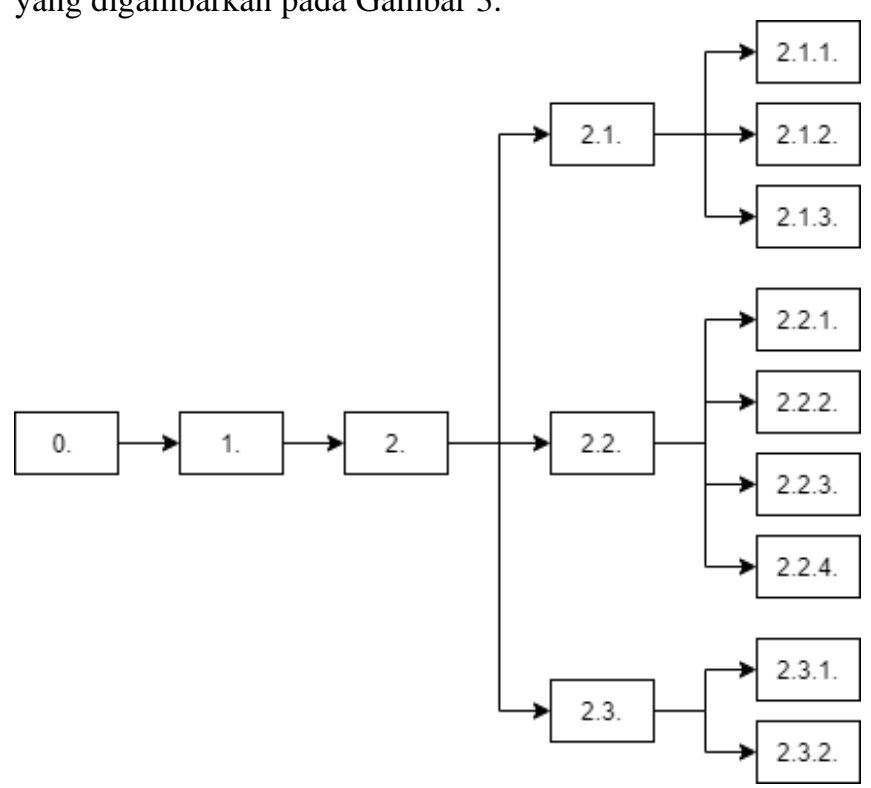

Gambar 3. Diagram HTA Dashboard

Setelah terlihat struktur dashboard menggunakan metode HTA, kemudian dilakukan perancangan kerangka desain yang digambarkan pada Gambar 4 - 6. Kerangka tersebut mengambarkan masing-masing kebutuhan yang dijabarkan pada Tabel V.

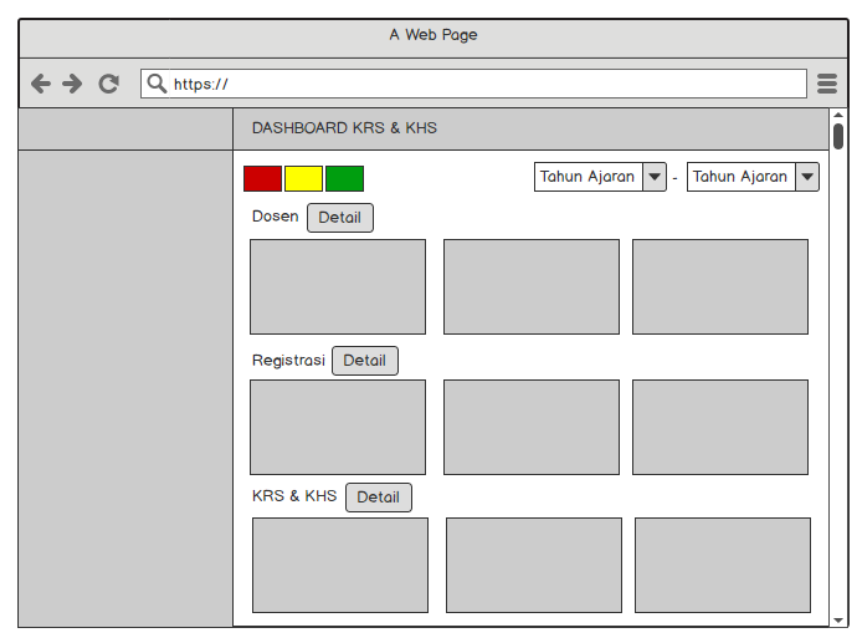

Gambar 4. Mock up tampilan Home
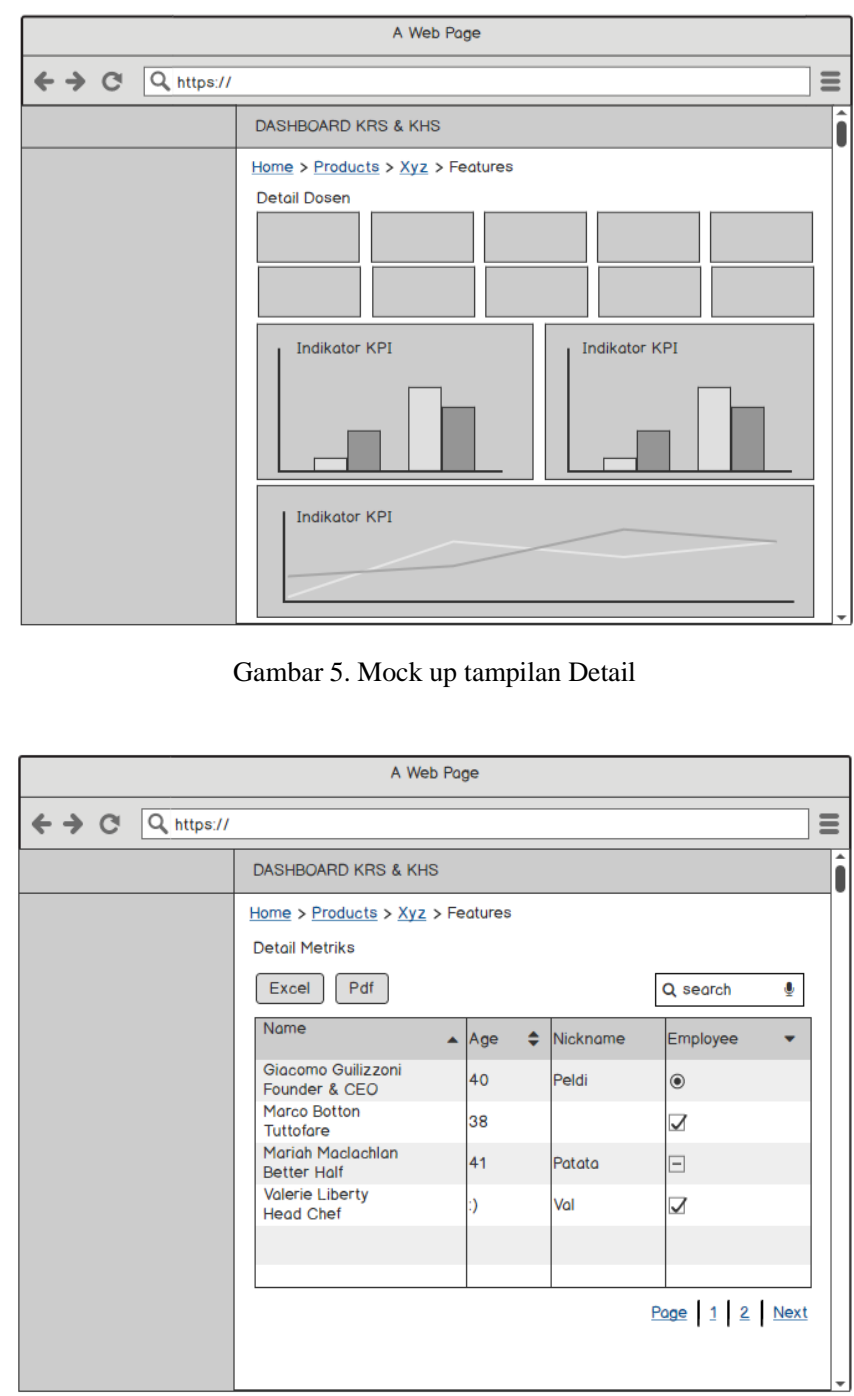

Gambar 6. Mock up tampilan Metriks 


\section{HASIL DAN PEMBAHASAN}

\section{A. Refinement}

Pada tahap ini, merupakan tahap yang serupa dengan tahap framework akan tetapi, pada tahap ini akan meningkatkan fokus pada detail dan implementasi. Beberapa tugas digabungkan menggunakan skenario validasi berdasarkan cerita atau sesuatu yang ditetapkan [11]. Tahap ini dihasilkan implementasi dashboard dari tahap framework yang digambarkan pada Gambar 7 - 9.

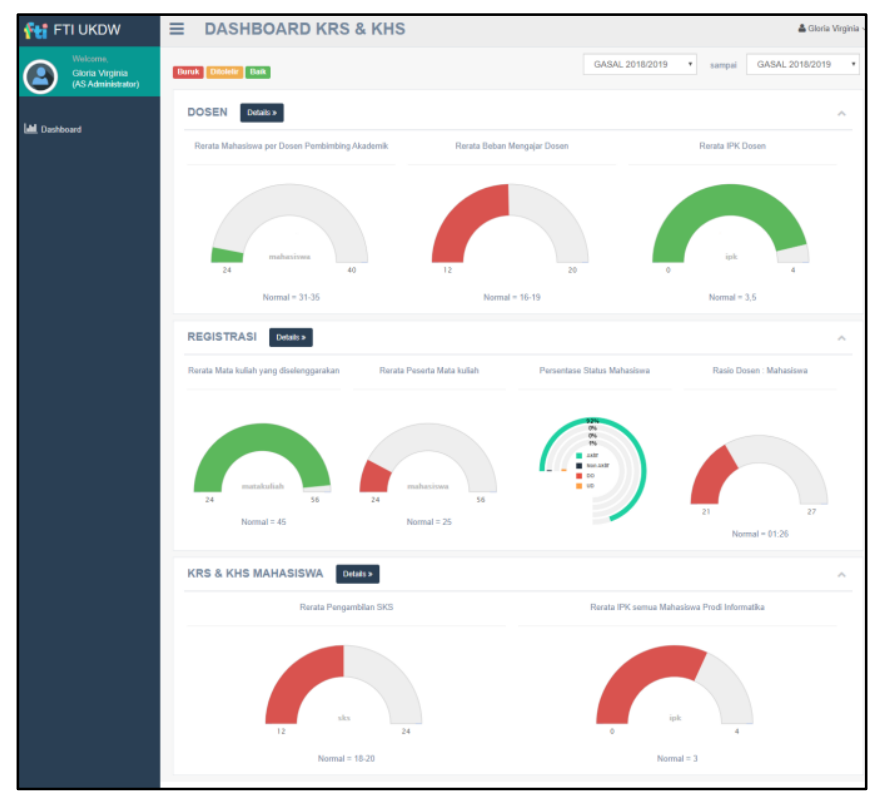

Gambar 7. Tampilan Home Dashboard

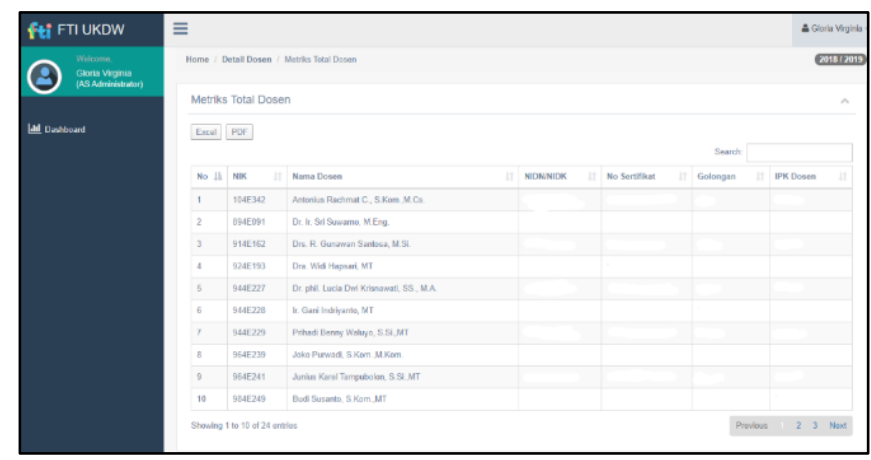

Gambar 8. Contoh Tampilan Report Dashboard

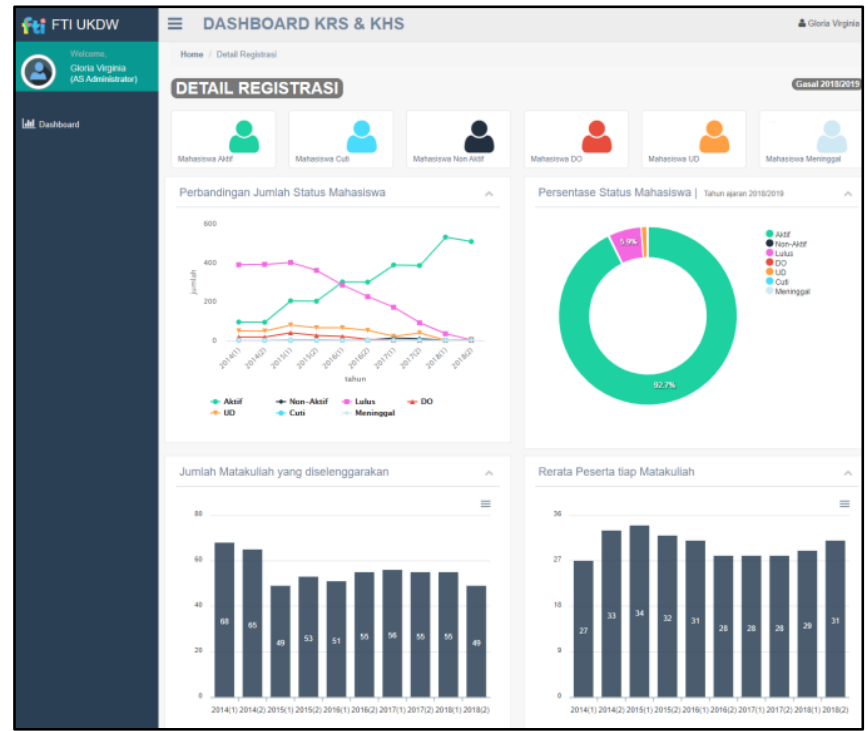

Gambar 9. Contoh Tampilan Detail Dashboard

\section{B. Development Support: Usability Test}

1) Sampel Size: jumlah responden ditentukan dengan persamaan yang ditemukan oleh [13]. Summative non estimating values merupakan metode yang menggunakan effect size (e) untuk persamaannya. Effect size diperoleh dengan mengganti persamaan critical difference (d) ke dalam persamaan standar deviasi. Hal ini dikarenakan penelitian ini tidak mengetahui variabilitas pengukuran sebelumnya, karena ini adalah penelitian pertama sehingga tidak ada estimasi untuk menentukan critical difference.

Perhitungan tersebut dijabarkan dengan ketentuan sebagai berikut :

- Confidence level (CL) $=70 \% \rightarrow \alpha=30 \%=0,3$

- Target Critical Difference (d) $=0,33$ menit $\rightarrow$ nilai 0,33 merupakan waktu minimal yang dihasilkan ketika dilakukan pengujian pada salah satu task.

Sehingga dihasilkan jumlah sampel :

- $\mathrm{z}$-score dengan $70 \%$ confidence $=1,036$

- $\mathrm{CL} 70 \%$ maka $\alpha=30 \%=0,3 \rightarrow \alpha / 2=0,15$. Area pada tabel $\mathrm{Z}$ yang mewakili 0,15 adalah 1,036 .

$$
\begin{aligned}
n= & \frac{z^{2} s^{2}}{d^{2}}=\frac{1,036^{2}(s)^{2}}{0,33^{2}(s)^{2}}=\frac{1,073}{0,111} \\
& =9,66 \text { dibulatkan menjadi } 10
\end{aligned}
$$

- $\mathrm{t}$-score dengan $\mathrm{n}=10,(\mathrm{df}=10-1=9)$

$\rightarrow \mathrm{t}($ two-tailed $)=0,3 / 2=0,15$ adalah 1,1

$$
\begin{aligned}
n= & \frac{z^{2} s^{2}}{d^{2}}=\frac{1,1^{2}(s)^{2}}{0,33^{2}(s)^{2}}=\frac{1,21}{0,111} \\
& =11,11 \text { dibulatkan menjadi } 11
\end{aligned}
$$


- $\mathrm{t}$-score dengan $\mathrm{n}=11,(\mathrm{df}=11-1=10)$

$\rightarrow \mathrm{t}($ two-tailed $)=0,3 / 2=0,15$ adalah 1,093

$$
\begin{aligned}
n= & \frac{z^{2} s^{2}}{d^{2}}=\frac{1,093^{2}(s)^{2}}{0,33^{2}(s)^{2}}=\frac{1,195}{0,111} \\
& =10,97 \text { dibulatkan menjadi } 11
\end{aligned}
$$

- $\mathrm{t}$-score dengan $\mathrm{n}=11,(\mathrm{df}=11-1=10)$

$\rightarrow \mathrm{t}($ two-tailed $)=0,3 / 2=0,15$ adalah 1,093

$$
\begin{aligned}
n= & \frac{z^{2} s^{2}}{d^{2}}=\frac{1,093^{2}(s)^{2}}{0,33^{2}(s)^{2}}=\frac{1,195}{0,111} \\
& =10,97 \text { dibulatkan menjadi } 11
\end{aligned}
$$

Jadi, responden yang dibutuhkan untuk pengujian, minimal adalah 11 orang. Sebanyak 15 responden melakukan pengujian dimana terdapat 1 data responden yang dianggap tidak valid. Responden yang dipilih merupakan Kaprodi di UKDW, Dekanat Informatika, Tim Akreditasi Informatika dan Staff PPA.

2) Performance Metric: Performance metric digunakan untuk menguji usability dari dashboard. Terdapat 5 prinsip dasar pengujian, yaitu time on task, task success, errors, efficiency dan learnability. Pada penelitian ini, pengujian learnability tidak digunakan karena, pegujian dashboard hanya dilakukan sekali, sehingga tidak dapat dibandingkan performa dari pengujian sebelum dan sesudahnya. Performance metric dilakukan berdasarkan task yang telah ditentukan dengan mengacu pada permasalahan yang ada. Terdapat 8 taks yang dipilih berdasarkan KPI yang dibuat berdasarkan penelitian [12].

\section{- Time on Task}

Cara yang paling umum untuk menganalisis data dari time on task adalah dengan melihat jumlah rata-rata yang dihabiskan oleh pengguna untuk tugas tertentu atau serangkaian tugas [14]. Terdapat 2 time on task yang dihitung berdasarkan task yang telah ditetapkan yaitu, time on task yang dihasilkan dari pengujian dan time on task yang dihasilkan dari pengujian ke 14 responden. Tabel VI merupakan hasil dari pengujian yang dilakukan dalam penelitian ini dan akan dijadikan batas waktu. Pada kolom batas waktu, hasil rata-rata per task dikalikan dengan 4 karena menurut [14] bahwa pengguna membutuhkan waktu 4 kali lebih lama untuk menyelesaikan tugas dari yang diharapkan, sehingga hal ini yang menjadi acuan untuk

\begin{tabular}{|c|c|c|c|c|c|}
\hline Task &  & 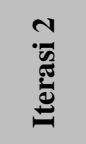 & 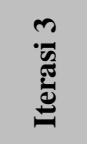 & $\sum_{\Sigma}^{\text {ङ }}$ &  \\
\hline 1 & 8 & 11 & 11 & 10,00 & 40,00 \\
\hline 2 & 8 & 9 & 8 & 8,33 & 33,33 \\
\hline 3 & 24 & 20 & 24 & 22,67 & 90,67 \\
\hline 4 & 13 & 19 & 18 & 16,67 & 66,67 \\
\hline 5 & 16 & 21 & 26 & 21,00 & 84,00 \\
\hline 6 & 19 & 21 & 13 & 17,67 & 70,67 \\
\hline 7 & 20 & 27 & 17 & 21,33 & 85,33 \\
\hline 8 & 27 & 26 & 21 & 24,67 & 98,67 \\
\hline Mean & 16,88 & 19,25 & 17,25 & 17,79 & 71,17 \\
\hline
\end{tabular}
menentukan batas waktu untuk setiap tasknya.
TABEL VI

BATAS WAKTU/AMBANG BATAS (DETIK)

Hasil dari pengujian ke 14 responden, dihasilkan time on task pada Tabel VII. Cell yang berwarna merah merupakan responden yang menyerah ketika mengerjakan task, cell berwarna kuning merupakan responden yang gagal mengerjakan task, sedangkan cell berwarna oranye merupakan waktu yang digunakan responden untuk sekali tugas > 100 detik. Batas waktu yang diujikan ditandai dengan cell berwarna ungu dan digunakan sebagai standar menentukan nilai pada tahap selanjutnya yaitu tahap binary

\begin{tabular}{|c|c|c|c|c|c|c|c|c|c|}
\hline $\begin{array}{c}\text { Tas } \\
\mathbf{k}\end{array}$ & 1 & 2 & 3 & 4 & 5 & 6 & 7 & 8 & $\begin{array}{c}\text { M } \\
\text { ea } \\
\mathbf{n}\end{array}$ \\
\hline  & $\begin{array}{l}8 \\
8 \\
8\end{array}$ & $\begin{array}{l}m \\
m\end{array}$ & бo & $\begin{array}{l}6 \\
6\end{array}$ & $\begin{array}{l}8 \\
\dot{\infty}\end{array}$ &  & $\begin{array}{l}m \\
\infty \\
\infty\end{array}$ & $\begin{array}{l}\hat{\sigma} \\
\infty\end{array}$ & 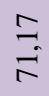 \\
\hline $\mathrm{R} 1$ & 23 & 37 & 95 & 25 & 29 & 20 & 35 & 45 & $\underset{\infty}{\infty}$ \\
\hline $\mathrm{R} 2$ & 17 & 13 & 73 & 18 & 12 & 34 & 25 & 30 & $\stackrel{n}{\curvearrowright}$ \\
\hline R3 & 32 & 12 & 34 & 37 & 47 & 18 & 73 & 53 & $\stackrel{\sim}{\sim}$ \\
\hline R4 & 54 & 45 & 38 & 15 & 34 & 20 & 16 & 39 & $\begin{array}{l}\hat{\sigma} \\
\text { ñ }\end{array}$ \\
\hline R5 & 20 & 52 & 93 & 63 & 48 & 33 & 40 & 53 & กิ \\
\hline R6 & 35 & 26 & 41 & 19 & $\begin{array}{c}10 \\
0\end{array}$ & 34 & 79 & 46 & 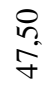 \\
\hline
\end{tabular}
success.

TABEL VII

HASIL TIME ON TASK RESPONDEN (DETIK) 
TABEL VII

HASIL TIME ON TASK RESPONDEN (DETIK)

\begin{tabular}{|c|c|c|c|c|c|c|c|c|c|}
\hline $\begin{array}{c}\text { Tas } \\
\mathbf{k}\end{array}$ & 1 & 2 & 3 & 4 & 5 & 6 & 7 & 8 & $\begin{array}{c}\text { M } \\
\text { ea } \\
\text { n }\end{array}$ \\
\hline 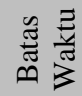 & $\stackrel{8}{8}$ & $m$ & $\begin{array}{l}\hat{0} \\
\hat{8}\end{array}$ & $\begin{array}{l}6 \\
6\end{array}$ & $\begin{array}{l}8 \\
\dot{0} \\
\dot{\infty}\end{array}$ & î́ & $\begin{array}{l}m \\
m \\
\infty\end{array}$ & $\begin{array}{l}\hat{b} \\
\infty \\
0\end{array}$ & $=$ \\
\hline R7 & 19 & 28 & 88 & 36 & 20 & 28 & 24 & 36 & $\begin{array}{l}\infty \\
\infty \\
\dot{m}\end{array}$ \\
\hline $\mathrm{R} 8$ & 19 & 20 & 117 & 19 & 27 & 19 & 32 & 32 & שु \\
\hline R9 & 15 & 27 & 65 & 20 & 38 & 20 & 39 & 29 & $\underset{m}{m}$ \\
\hline $\mathrm{R} 10$ & 23 & 44 & 39 & 15 & 99 & 23 & 49 & 30 & ֻூ \\
\hline R11 & 43 & 39 & 66 & 99 & 46 & 55 & 32 & 37 & $\frac{m}{n}$ \\
\hline R12 & 16 & 12 & 140 & 16 & 40 & 15 & 65 & 51 & $\stackrel{\infty}{m}$ \\
\hline R13 & 24 & 99 & 40 & 44 & 90 & 30 & 128 & 45 & กำ \\
\hline R14 & 12 & 9 & 29 & 15 & 49 & 16 & 53 & 70 & $\underset{n}{n}$ \\
\hline$\sum_{\Sigma}^{\mathbb{E}}$ & $\frac{\nabla}{2}$ & $\begin{array}{l}\hat{0} \\
\text { ñ }\end{array}$ & $\begin{array}{l}\stackrel{m}{+} \\
\infty \\
0\end{array}$ & $\frac{0}{n}$ & $\begin{array}{l}0 \\
\stackrel{n}{0} \\
\infty\end{array}$ & $\begin{array}{l}\hat{0} \\
\text { ते }\end{array}$ & ภิ & in & in \\
\hline  & $\frac{n}{n}$ & $\stackrel{\circ}{\text { ก }}$ & $\begin{array}{l}\text { ? } \\
\text { ñ }\end{array}$ & ํำ & $\underset{8}{\stackrel{8}{+}}$ & $\frac{n}{n}$ & กิ & $\begin{array}{l}8 \\
\stackrel{7}{7}\end{array}$ & 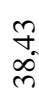 \\
\hline
\end{tabular}

Terdapat 3 responden yang memiliki waktu pengerjaan diatas 100 detik (cell berwarna oranye). Hal ini dikarenakan responden cukup kesulitan dalam memahami task yang diberikan, sehingga responden harus mencari cara untuk menyelesaikan tasknya dengan mengubah-ubah tahun ajaran. Selain itu waktu yang dihasilkan cukup banyak pada task 7 , hal ini dikarenakan responden yang salah memilih kategori detail dari task yang ditanyakan, sehingga waktu yang dibutuhkan menjadi lebih lama.

\section{- Task success : Binary Success}

Task success merupakan tugas yang diujikan dapat diselesaikan dengan baik sesuai dengan jawaban yang telah ditetapkan [14]. Dari 8 task, responden akan diberikan nilai 1 jika mengerjakan task dengan benar, dan nilai 0 bagi yang salah. Cell merah pada Tabel VIII menunjukan responden yang menyerah ketika menjalankan task, sedangkan cell yang berwarna kuning adalah responden yang salah memberikan jawaban saat pengujian.

TABEL VIII

HASIL PENGUJIAN BINARY SUCCESS

\begin{tabular}{|l|l|l|l|l|l|l|l|l|l|}
\hline \multicolumn{1}{|c|}{ Task } & $\mathbf{1}$ & $\mathbf{2}$ & $\mathbf{3}$ & $\mathbf{4}$ & $\mathbf{5}$ & $\mathbf{6}$ & $\mathbf{7}$ & $\mathbf{8}$ & Success \\
\hline R1 & 1 & 0 & 0 & 1 & 1 & 0 & 1 & 1 & $63 \%$ \\
\hline R2 & 0 & 0 & 0 & 1 & 1 & 1 & 1 & 1 & $63 \%$ \\
\hline R3 & 1 & 1 & 1 & 1 & 0 & 0 & 1 & 1 & $75 \%$ \\
\hline R4 & 0 & 0 & 0 & 1 & 1 & 1 & 0 & 1 & $50 \%$ \\
\hline R5 & 1 & 0 & 0 & 0 & 1 & 1 & 0 & 1 & $50 \%$ \\
\hline R6 & 1 & 1 & 1 & 1 & 0 & 1 & 0 & 1 & $75 \%$ \\
\hline R7 & 0 & 1 & 1 & 1 & 1 & 1 & 1 & 1 & $88 \%$ \\
\hline R8 & 1 & 1 & 0 & 1 & 1 & 1 & 1 & 1 & $88 \%$ \\
\hline R9 & 1 & 1 & 1 & 1 & 1 & 1 & 1 & 1 & $100 \%$ \\
\hline R10 & 1 & 0 & 1 & 1 & 0 & 1 & 1 & 1 & $75 \%$ \\
\hline R11 & 0 & 0 & 0 & 0 & 1 & 1 & 1 & 1 & $50 \%$ \\
\hline R12 & 1 & 1 & 0 & 1 & 1 & 0 & 1 & 1 & $75 \%$ \\
\hline R13 & 1 & 0 & 1 & 1 & 0 & 1 & 0 & 1 & $63 \%$ \\
\hline R14 & 1 & 1 & 0 & 1 & 1 & 1 & 1 & 0 & $75 \%$ \\
\hline $\begin{array}{l}\text { Success } \\
\text { (\%) }\end{array}$ & 71 & 50 & 43 & 86 & 71 & 79 & 71 & 93 & $71 \%$ \\
\hline
\end{tabular}

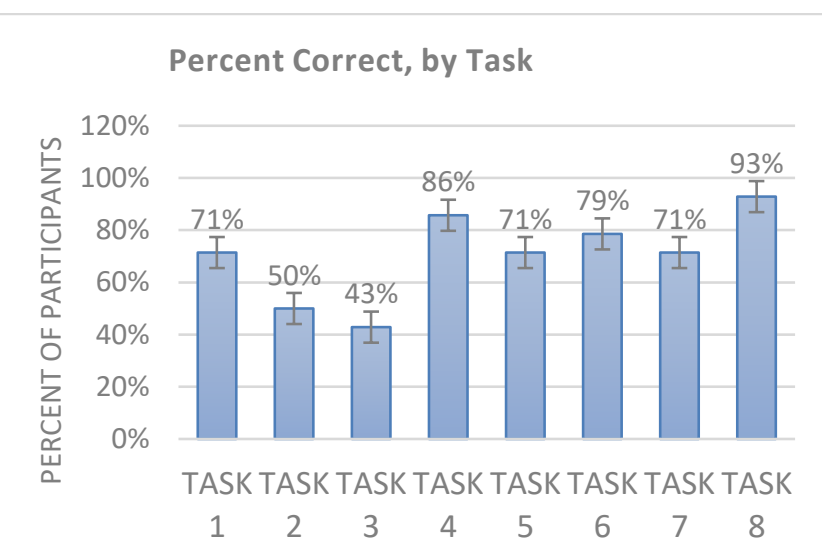

Gambar 10. Grafik Task Success : Binary Success

Task 8 memiliki tingkat kesuksesan tertinggi, sedangkan task 3 memiliki tingkat kesuksesan ter rendah yang digambarkan pada Gambar 10. Hal yang melatar belakangi task 3 memiliki tingkat kesuksesan terendah karena responden yang kesulitan dalam memahami task yang diberikan. Pengujian ini menghasilkan nilai $71 \%$ untuk user interface dashboard dimana pada Tabel IX termasuk kategori baik. 
TABEL IX

KATEGORI NILAI USER INTERFACE

\begin{tabular}{|c|c|}
\hline Nilai & Kategori \\
\hline $0-33 \%$ & Buruk \\
\hline $33-66 \%$ & Cukup \\
\hline $66-100 \%$ & Baik \\
\hline
\end{tabular}

\section{- Error}

Error merupakan kesalahan yang dilakukan pengguna ketika menjalankan sebuah tugas. Contoh kesalahan yang terjadi adalah ketika pengguna salah memasukan data dan ketika kesalahan pengguna mengakibatkan kegagalan tugas [14]. Cell yang berwarna oranye menunjukan keadaan dimana pada bagian task success dengan pengujian binary success, responden gagal dalam menjalankan task (binary success $=0$ ). Hal ini tidak dapat dijadikan acuan untuk menentukan sukses atau gagalnya responden dalam mengerjakan task. Beberapa kasus menujukan bahwa responden yang gagal menyelesaikan task dengan waktu tertentu, belum pasti salah dalam pengerjaan task. Cell berwarna hijau pada Tabel $\mathrm{X}$ menunjukan responden tidak melakukan kesalahan dalam pengerjaan task, akan tetapi responden tidak dapat mengerjakan task dengan batas waktu yang telah ditentukan.

TABEL $\mathrm{X}$

HASIL PENGUJIAN ERROR

\begin{tabular}{|c|c|c|c|c|c|c|c|c|c|}
\hline Task & 1 & 2 & 3 & 4 & 5 & 6 & 7 & 8 & Sum \\
\hline R1 & 0 & 1 & 1 & 0 & 0 & 1 & 0 & 0 & 3 \\
\hline R2 & 1 & 1 & 2 & 1 & 1 & 0 & 0 & 0 & 6 \\
\hline R3 & 0 & 0 & 0 & 0 & 1 & 1 & 0 & 0 & 2 \\
\hline R4 & 2 & 2 & 4 & 0 & 0 & 0 & 1 & 0 & 9 \\
\hline R5 & 0 & 1 & 1 & 1 & 0 & 1 & 1 & 0 & 5 \\
\hline R6 & 0 & 0 & 0 & 0 & 1 & 0 & 1 & 0 & 2 \\
\hline R7 & 1 & 0 & 1 & 0 & 0 & 0 & 0 & 0 & 2 \\
\hline R8 & 0 & 0 & 1 & 0 & 0 & 0 & 0 & 0 & 1 \\
\hline R9 & 0 & 0 & 0 & 0 & 0 & 0 & 0 & 0 & 0 \\
\hline R10 & 0 & 1 & 0 & 0 & & 0 & 0 & 0 & 1 \\
\hline R11 & 1 & 1 & 1 & & 0 & 0 & 0 & 0 & 3 \\
\hline $\mathrm{R} 12$ & 0 & 0 & 1 & 0 & 0 & 1 & 0 & 0 & 2 \\
\hline $\mathrm{R} 13$ & 0 & & 0 & 0 & 0 & 0 & 7 & 0 & 7 \\
\hline R14 & 0 & 0 & 1 & 0 & 0 & 0 & 0 & 1 & 2 \\
\hline Jumlah & 5 & 7 & 13 & 2 & 3 & 4 & 10 & 1 & \\
\hline
\end{tabular}

Gambar 11 menunjukan bahwa jumlah error pada task 3 memiliki nilai terbanyak, sedangkan task 8 memiliki jumlah error paling sedikit.



Gambar 11. Grafik Error by task

\section{- Efficiency}

Efficiency merupakan kegiatan mengukur jumlah tindakan atau langkah yang diambil pengguna dalam melakukan setiap tugas. Suatu tindakan dapat dilakukan dalam berbagai bentuk seperti mengklik tautan pada halaman web. Semakin banyak tindakan/klik yang dilakukan pengguna maka semakin banyak pula upaya yang dilakukan [14]. Semua jumlah klik yang dilakukan oleh responden akan direkap untuk dibandingkan dengan minimal klik yang telah ditetapkan dan dijabarkan pada Tabel XI dengan cell berwarna ungu.

TABEL XI

HASIL PENGUJIAN EFFICIENCY

\begin{tabular}{|c|c|c|c|c|c|c|c|c|c|}
\hline Task & 1 & 2 & 3 & 4 & 5 & 6 & 7 & 8 & $\begin{array}{c}\mathrm{Su} \\
\mathbf{m}\end{array}$ \\
\hline$\dot{\bar{\Sigma}} \overline{\mathrm{I}}$ & 2 & 2 & 3 & 4 & 4 & 5 & 3 & 3 & 26 \\
\hline R1 & 2 & 3 & 3 & 4 & 4 & 2 & 3 & 4 & 25 \\
\hline $\mathrm{R} 2$ & 1 & 1 & 2 & 4 & 4 & 7 & 5 & 3 & 27 \\
\hline R3 & 2 & 16 & 7 & 4 & 8 & 1 & 6 & 5 & 49 \\
\hline $\mathrm{R} 4$ & 9 & 9 & 10 & 4 & 4 & 7 & 11 & 3 & 57 \\
\hline R5 & 2 & 2 & 6 & 3 & 4 & 5 & 7 & 3 & 32 \\
\hline R6 & 2 & 2 & 7 & 4 & 8 & 5 & 6 & 3 & 37 \\
\hline R7 & 4 & 2 & 3 & 4 & 14 & 5 & 3 & 3 & 38 \\
\hline $\mathrm{R} 8$ & 4 & 6 & 8 & 4 & 5 & 6 & 5 & 3 & 41 \\
\hline R9 & 2 & 3 & 9 & 4 & 8 & 5 & 4 & 3 & 38 \\
\hline R10 & 6 & 3 & 3 & 6 & 4 & 12 & 8 & 3 & 45 \\
\hline R11 & 2 & 2 & 4 & - & 5 & 9 & 3 & 3 & 28 \\
\hline $\mathrm{R} 12$ & 2 & 2 & 6 & 4 & 5 & 5 & 5 & 4 & 33 \\
\hline $\mathrm{R} 13$ & 2 & - & 1 & 0 & 8 & 7 & 17 & 6 & 41 \\
\hline R14 & 2 & 2 & 4 & 4 & 8 & 5 & 4 & 5 & 34 \\
\hline Sum & 42 & 53 & 73 & 49 & 89 & 81 & 87 & 51 & \\
\hline Mean & 8 & $\stackrel{\infty}{\stackrel{0}{+}}$ & $\vec{v}$ & $\stackrel{\hat{m}}{m}$ & 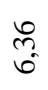 & $\frac{2}{i}$ & $\begin{array}{l}\bar{\imath} \\
\hat{0}\end{array}$ & $\underset{\text { r }}{+}$ & \\
\hline
\end{tabular}

Cell yang berwarna oranye merupakan tanda bahwa 
responden tersebut pada bagian binary success mengalami kegagalan. Beberapa jumlah klik yang dilakukan responden dalam menjalankan sebuah task, kurang dari minimal klik yang ditetapkan. Akan tetapi hal yang bertentangan juga muncul pada data dengan cell yang berwarna hijau. Data dengan cell berwarna hijau merupakan responden yang mengalami kesuksesan dalam menjalankan task, dengan jumlah klik dibawah batas minimal klik yang ditetapkan. Hal ini disebabkan karena responden yang menjalankan task tidak menggunakan tahun ajaran untuk mengerjakan sebuah task, akan tetapi langsung menuju halaman detail dosen dan mencari informasi tersebut secara langsung. Hal ini dianggap dapat dilakukan responden karena responden memilih kategori dengan benar, sehingga tidak terhitung sebagai sebuah kesalahan.

Tabel XII menujukan selisih hasil perbandingan dari pengujian efficiency, dimana task 4 memiliki selisih dibawah batas minimal klik yang telah ditetapkan, sedangkan pada task 7 memiliki selisih terbanyak dengan batas minimal klik yang telah ditetapkan. Hal ini, dapat disimpulkan bahwa pada pengujian efficiency, task 4 lebih efisien daripada task 7. Gambar 12 menampilkan grafik perbandingan selisih task pada pengujian efficiency.

TABEL XII

HASIL SELISIH EFFICIENCY BY TASK

\begin{tabular}{|c|c|c|c|}
\hline Task & $\begin{array}{c}\text { Rerata } \\
\text { Efficiency }\end{array}$ & $\begin{array}{c}\text { Batas Min } \\
\text { Klik }\end{array}$ & Selisih \\
\hline 1 & 3,00 & 2 & 2,00 \\
\hline 2 & 4,08 & 2 & 2,08 \\
\hline 3 & 5,21 & 3 & 2,21 \\
\hline 4 & 3,77 & 4 & $-0,23$ \\
\hline 5 & 6,36 & 4 & 2,36 \\
\hline 6 & 5,79 & 5 & 0,79 \\
\hline 7 & 6,21 & 3 & 3,21 \\
\hline 8 & 3,64 & 3 & 0,64 \\
\hline Mean & 4,76 & 3,25 & 1,63 \\
\hline
\end{tabular}

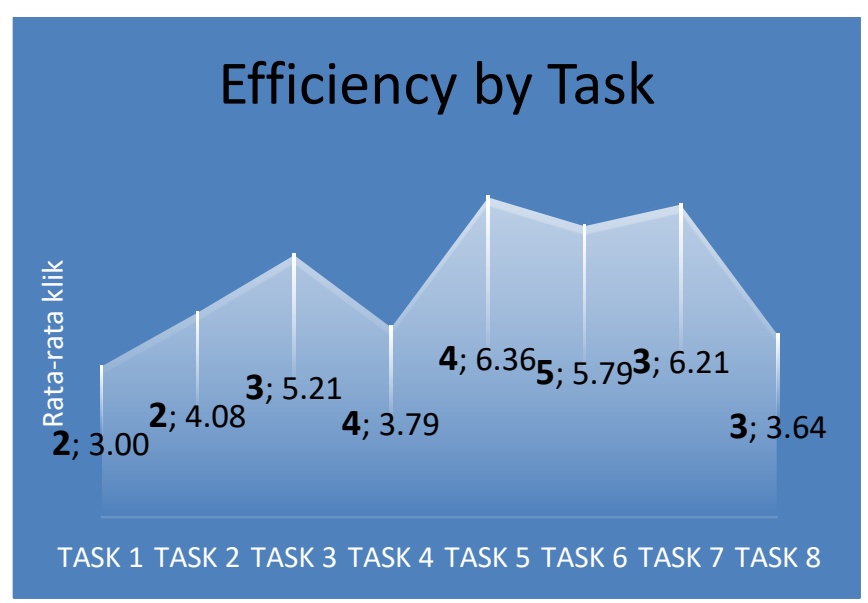

Gambar 12. Grafik Efficiency by task

Hasil keseluruhan pengujian user interface pada Tabel
XIII menggunakan metode Performance metric: binary success menghasilkan nilai $71 \%$ sehingga dashboard dapat dikatakan baik dengan acuan dari Tabel IX. Sedangkan pada bagian efficiency menghasilkan nilai 4,75 dengan rata-rata batas minimal klik adalah 3,25. Rata-rata waktu pengerjaan task yaitu 40,57 dengan jumlah error rata-rata 5,62 dibulatkan menjadi 6 error. Faktor yang melatar belakangi terjanjinya kesalahan dalam pengerjaan task yaitu faktor demografi responden, dimana responden yang tidak memiliki latar belakang IT cenderung lebih lama dalam pengerjaan task.

TABEL XIII

HASil RATA-RATA PERFORMANCE METRIC

\begin{tabular}{|c|c|c|c|c|}
\hline Task &  & 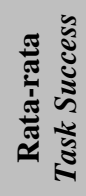 & 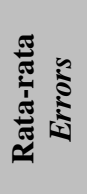 & \\
\hline 1 & 25,14 & $71 \%$ & 5 & 3,00 \\
\hline 2 & 33,07 & $50 \%$ & 7 & 4,08 \\
\hline 3 & 68,43 & $43 \%$ & 13 & 5,21 \\
\hline 4 & 31,5 & $86 \%$ & 2 & 3,77 \\
\hline 5 & 48,5 & $71 \%$ & 3 & 6,36 \\
\hline 6 & 26,07 & $79 \%$ & 4 & 5,79 \\
\hline 7 & 49,29 & $71 \%$ & 10 & 6,21 \\
\hline 8 & 42,57 & $93 \%$ & 1 & 3,64 \\
\hline Sum & 324,57 & $564 \%$ & 45 & 38,06 \\
\hline Mean & 40,57 & $71 \%$ & 5,62 & 4,75 \\
\hline
\end{tabular}

\section{3) Evaluasi: $U E Q$}

UEQ merupakan suatu tools yang digunakan untuk pengolahan data survei terkait penggalaman pengguna yang mudah untuk dipraktikan, dapat dipercaya, berdasar, dan dimanfaatkan untuk melakukan penilaian kualiatas subjektif. Skala kuesioner UEQ dirancang untuk mencakup kesan/persepsi tentang penggalaman pengguna secara menyeluruh yang terdiri dari 26 pertanyaan [7].

Inkonsistensi data merupakan pengecekan jawaban kuesioner responden terhadap sistem yang dianggap tidak serius dalam menggerjakannya. Hal ini dapat terjadi jika kuesioner UEQ dilakukan secara daring, untuk menguji jawaban acak ini, digunakan metode heuristik sederhana. Dalam suatu skala, semua item mengukur aspek UX yang serupa, harus mempunyai jawaban yang serupa pula. Jika terdapat perbedaan mencolok (lebih dari 3), akan lebih baik jawaban/kuesioner tersebut dihapus [7].

TABEL IX

SKALA INKONSISTENSI JAWABAN RESPONDEN

\begin{tabular}{|c|c|c|c|c|c|c|}
\hline $\begin{array}{c}\text { Daya } \\
\text { tarik }\end{array}$ & $\begin{array}{c}\text { Kejel } \\
\text { asan }\end{array}$ & $\begin{array}{c}\text { Efisi } \\
\text { ensi }\end{array}$ & $\begin{array}{c}\text { Ketep } \\
\text { atan }\end{array}$ & $\begin{array}{c}\text { Stimu } \\
\text { lasi }\end{array}$ & $\begin{array}{c}\text { Kebar } \\
\text { uan }\end{array}$ & $\begin{array}{c}\text { Criti } \\
\text { cal? }\end{array}$ \\
\hline & & & & & & 0 \\
\hline
\end{tabular}


TABEL IX

SKALA INKONSISTENSI JAWABAN RESPONDEN

\begin{tabular}{|c|c|c|c|c|c|c|}
\hline $\begin{array}{c}\text { Daya } \\
\text { tarik }\end{array}$ & $\begin{array}{c}\text { Kejel } \\
\text { asan }\end{array}$ & $\begin{array}{c}\text { Efisi } \\
\text { ensi }\end{array}$ & $\begin{array}{c}\text { Ketep } \\
\text { atan }\end{array}$ & $\begin{array}{c}\text { Stimu } \\
\text { lasi }\end{array}$ & $\begin{array}{c}\text { Kebar } \\
\text { uan }\end{array}$ & $\begin{array}{c}\text { Criti } \\
\text { cal? }\end{array}$ \\
\hline & & & & & & 0 \\
\hline & & & & & & 0 \\
\hline & & 1 & & & & 1 \\
\hline & 1 & & & & & 1 \\
\hline & & & & 1 & & 1 \\
\hline & & & & & 1 & 1 \\
\hline & & & & & 1 & 1 \\
\hline & & & & & & 0 \\
\hline & & & & & & 0 \\
\hline & & 1 & 1 & & & 2 \\
\hline & & & & & & 0 \\
\hline & & & & & & 0 \\
\hline & & & & & & 0 \\
\hline
\end{tabular}

Selain itu, Koefisien cronbach alpha mendeskripsikan konsistensi untuk semua item pada semua skala untuk mengecek reliabilitas kuesioner. Suatu data dikatakan memiliki konsistensi yang tinggi jika nilai dari koefisien cronbach alpha lebih besar atau sama dengan 0,7 [7]. Tabel $\mathrm{X}$ menunjukan nilai yang kurang dari 0,7 yaitu 0,62 adalah dependability/ketepatan. Sehingga pada aspek dependability tidak akan di perhatikan. Pertanyaan yang berkaitan dengan ketepatan yaitu tak dapat diprediksi - dapat diprediksi, menghalangi - mendukung, aman - tidak aman, dan memenuhi ekspektasi - tidak memenuhi ekspektasi.

TABEL $\mathrm{X}$

KOEFISIEN RELIABILITAS CRONBACH ALPHA

\begin{tabular}{|c|c|}
\hline Scale & Cronbach Alpha \\
\hline Attractiveness & 0,94 \\
\hline Perspicuity & 0,70 \\
\hline Efficiency & 0,76 \\
\hline Dependability & 0,62 \\
\hline Stimulation & 0,75 \\
\hline Novelty & 0,70 \\
\hline
\end{tabular}

Tabel XI merupakan hasil perhitungan mean dan variance yang menunjukan bahwa dari keenam skala, semua menghasilkan nilai positif (dengan penanda panah hijau ke atas). Gambar 13 menampilkan hasil perhitungan dalam bentuk grafik. Terlihat bahwa ke enam skala memiliki nilai yang berada pada area berwarna hijau.

TABEL XI

SKALA UEQ (MEAN DAN VARIANCE)

\begin{tabular}{|l|c|c|}
\hline \multicolumn{3}{|c|}{ UEQ Scales (Mean and Variance) } \\
\hline Daya tarik & \\
\hline Kejelasan & 1,964 & 0,81 \\
\hline Efisiensi & 1,875 & 0,46 \\
\hline Ketepatan & 1,857 & 0,57 \\
\hline
\end{tabular}

\begin{tabular}{|l|c|c|}
\hline \multicolumn{3}{|c|}{ UEQ Scales (Mean and Variance) } \\
\hline Stimulasi & $N_{1,929}$ & 0,48 \\
\hline Kebaruan & $N_{1,768}$ & 0,75 \\
\hline
\end{tabular}

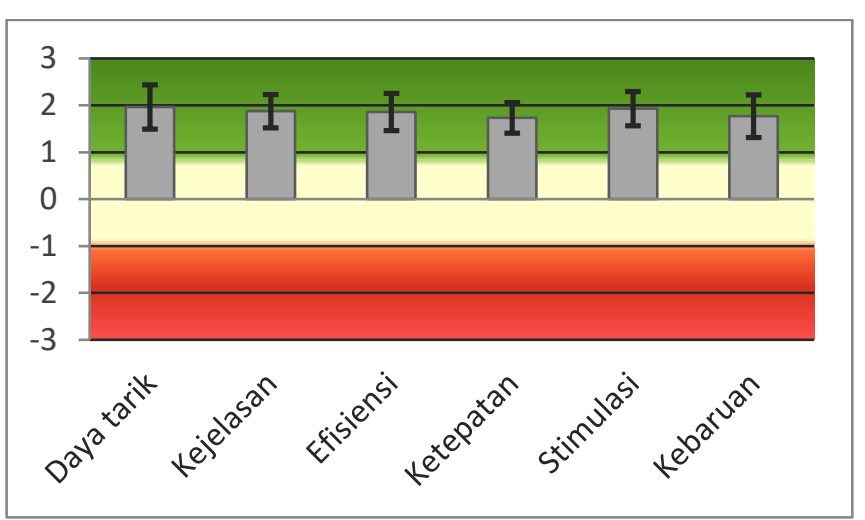

Gambar 13. Grafik Skala (Mean dan Variance)

Menurut [6] pengelompokan hasil evaluasi mean dan variance berdasarkan evaluasi negatif, normal, atau positif terkadang belum dapat memberikan pengertian yang aktual bagi para praktisi untuk menginterpretasikan hasil evaluasi terhadap sebuah produk apakah produk tersebut baik atau tidak? Terlebih lagi jika produk yang dievaluasi merupakan produk baru yang belum pernah dilakukan evaluasi UX, sehingga, belum mempunyai pembanding terhadap nilai yang dihasilkan, ataupun produk lama yang baru sekali dilakukan evaluasi UX [7]. Perbandingan dibuat oleh [6], untuk membandingkan data hasil kuesioner dengan mengumpulkan hasil pengujian UX yang pernah dilakukan terhadap produk yang menggunakan UEQ, kemudian dijadikan patokan untuk menentukan produk tersebut baik atau tidak. Hasil perbandingan dashboard dengan benchmark dataset tersaji dalam Tabel XII dan Gambar 14.

TABEL XII

SKALA UEQ (MEAN DAN VARIANCE)

\begin{tabular}{|c|c|c|c|}
\hline Scale & Mean & $\begin{array}{c}\text { Comparisson } \\
\text { to benchmark }\end{array}$ & Interpretation \\
\hline Daya tarik & 1,96 & Excellent & $\begin{array}{c}\text { In the range of } \\
\text { the } 10 \% \text { best } \\
\text { results }\end{array}$ \\
\hline Kejelasan & 1,88 & Good & $\begin{array}{c}10 \% \text { of results } \\
\text { better, } 75 \% \text { of } \\
\text { results worse }\end{array}$ \\
\hline Efisiensi & 1,86 & Good & $\begin{array}{c}\text { In the range of } \\
\text { the } 10 \% \text { best } \\
\text { results }\end{array}$ \\
\hline Ketepatan & 1,73 & Excellent & $\begin{array}{c}\text { In the range of } \\
\text { the } 10 \% \text { best } \\
\text { results }\end{array}$ \\
\hline Stimulasi & 1,93 & Excellent & $\begin{array}{c}\text { In the range of } \\
\text { the } 10 \% \text { best } \\
\text { results }\end{array}$ \\
\hline
\end{tabular}


TABEL XII

SKALA UEQ (MEAN DAN VARIANCE)

\begin{tabular}{|c|c|c|c|}
\hline Scale & Mean & $\begin{array}{c}\text { Comparisson } \\
\text { to benchmark }\end{array}$ & Interpretation \\
\hline Kebaruan & 1,77 & Excellent & $\begin{array}{c}\text { In the range of } \\
\text { the } 10 \% \text { best } \\
\text { results }\end{array}$ \\
\hline
\end{tabular}

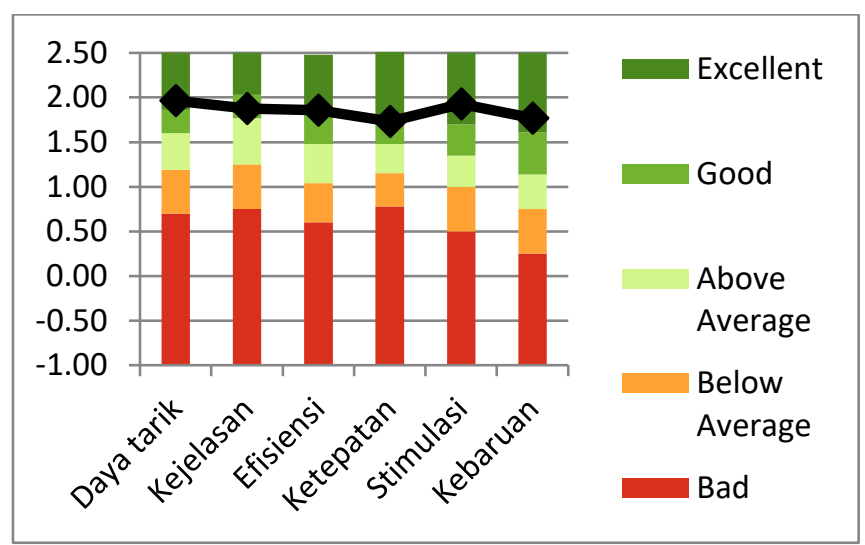

Gambar 14. Grafik Benchmark UEQ

Hasil Tabel XII, perbandingan skala daya tarik, stimulasi, kebaharuan mendapatkan nilai excellent, sedangkan skala kejelasan dan efisiensi mendapatkan nilai good. Pada skala ketepatan, pertanyaan yang ujikan tidak diperhatikan karena nilai dari cronbach alpha yang kurang dari 0,7 hal ini menjelaskan bahwa terdapat ketidak konsistensian data hasil kuesioner yang diujikan ke 14 orang responden pada skala ketepatan. Pertanyaan yang berkaitan dengan ketepatan yaitu tak dapat diprediksi - dapat diprediksi, menghalangi mendukung, aman - tidak aman, dan memenuhi ekspektasi tidak memenuhi ekspektasi.

\section{4) Design Modification}

Dari hasil analisis UI dan UX dengan menggunakan performance metric, UEQ, serta wawancara singkat dengan responden ketika pengujian. Pada tahap terakhir metode GDD dihasilkan beberapa modifikasi kecil. Beberapa masukan yang telah disampaikan oleh responden telah difilter dalam penelitian ini dan disetujui oleh Kaprodi Informatika selaku stakeholder yang menggunakan sistem. Perbaikan/modifikasi tesebut meliputi :

\section{- Judul Dashboard}

Judul dashboard yang ditetapkan pada dashboard sebelumnya hanya diletakkan pada halaman home, akan tetapi terdapat responden yang menyarankan untuk meletakkan judul besar dashboard pada navbar, sehingga judul dashboard akan muncul pada setiap halaman dashboard. Hal ini ditunjukan pada Gambar 15 sebelu di modifikasi yang kemudian di modifikasi menjadi Gambar 16.

\section{DASHBOARD KRS \& KHS}

Gambar 15. Judul Dasboard Sebelum Modifikasi

\section{DASHBOARD KRS \& KHS}

Gambar 16. Judul Dashboard Sesudah Modifikasi

\section{- Legend Indikator}

Keterangan dari indikator dashboard yang menyatakan bahwa dashboard itu masuk kategori baik, buruk dan dapat ditorerir pada Gambar 17 responden tidak dapat membaca dengan mudah keterangan indikatornya. Sehingga legend/keterangan dari indikator tersebut di modifikasi menjadi keterangan yang lebih terlihat dengan menggunakan label warna yang ditunjukan pada Gambar 18 .

\section{Keterangan Warna Merah=Buruk; Kuning=Ditolelir; $\mathrm{Hijau=Baik}$}

Gambar 17. Legend Indikator Sebelum Modifikasi

$$
\text { Buruk Ditolelir Baik }
$$

Gambar 18. Legend Indikator Setelah Modifikasi

\section{- Default Tahun ajaran Akhir}

Dropdown menu pada pojok kanan atas Gambar 19 yang menunjukan pilihan tahun ajaran tidak begitu diperhatikan oleh responden, hal ini yang menyebabkan responden memerlukan banyak klik dalam mencari jawaban pada task yang telah diujikan. Hal ini dianggap tidak efektif, akan tetapi dengan mengacu pada pola desain antarmuka yang dijelaskan oleh [15] secara baku pilihan seperti search dan pilihan tahun ajaran memang telah tepat di letakkan pada bagian pojok kanan atas. Hal ini dilakukan karena pengguna cenderung membaca data dengan cepat dari kiri ke kanan. Sehingga responden menyarankan untuk menambahkan default pada bagian dropdown menu yang ke 2 pada Gambar 20, sehingga responden mengetahui bahwa tahun ajaran dapat dipilih berdasarkan semester atau range tahun.



Gambar 19. Default Tahun Ajaran Sebelum Modifikasi

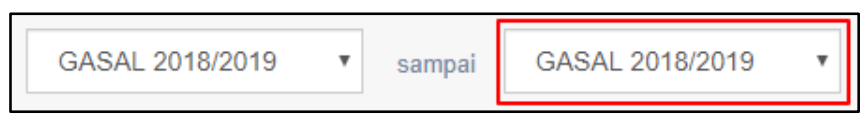

Gambar 20. Default Tahun Ajaran Sesudah Modifikasi 


\section{- Warna Icon}

Metriks yang ditampilkan dianggap kurang efektif jika ditampilkan dengan warna yang sama. Hal ini dikarenakan informasi metriks yang ditampilkan termasuk dalam kategori yang berbeda. Sehingga penggunaan warna digunakan untuk membantu Kaprodi dalam mengategorikan metriks. Setiap warna yang digunakan memiliki makna sebagai pembeda antar metriks. Pada Gambar 22 ditampilkan metriks pada halaman dosen yang telah dimodifikasi dari metriks pada Gambar 21.

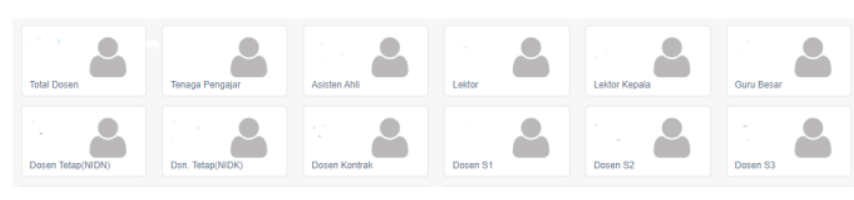

Gambar 21. Warna Icon Metriks Sebelum Modifikasi

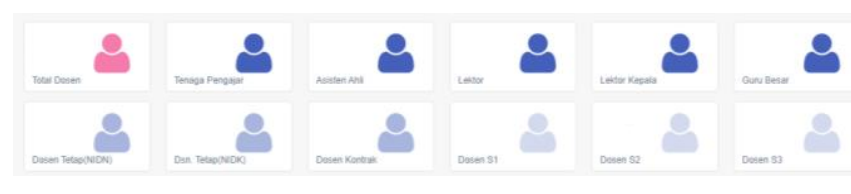

Gambar 23. Warna Icon Metriks Sesudah Modifikasi

- Informasi Tahun Ajaran

Informasi tahun ajaran yang ditampilkan pada setiap halaman detail dan report dianggap kurang, karena data yang ditampilkan berdasarkan semester, sehingga informasi tahun ajaran yang ditampilkan pada Gambar 24 dianggap kurang informatif. Sehingga keterangan semester yang ditunjukan pada Gambar 25 ditambahkan pada setiap halaman detail dan report.

\section{$2018 / 2019$}

Gambar 24. Informasi Tahun Ajaran Sebelum Modifikasi

\section{Gasal 2018/2019}

Gambar 25. Informasi Tahun Ajaran Sesudah Modifikasi

\section{SIMPULAN}

Dashboard dengan sumber data KRS \& KHS digunakan untuk membantu Kaprodi menganalisis data yang dibangun menggunakan metode GDD dengan tambahan metode Hirarchical Task Analysis untuk merumuskan tahap design framework. Evaluasi user interface dashboard menghasilkan nilai $71 \%$ pada penilaian binary success dan dikategorikan ke dalam kategori baik dengan menggunakan metode performance metrics. User experience pengguna menggunakan tools User Experience Questionnaire menghasilkan nilai excellent pada ke 3 skala penilaian yaitu daya tarik, stimulasi, kebaharuan. Selain itu nilai good pada skala kejelasan dan efisiensi. Modifikasi dashboard dilakukan dengan memodifikasi 5 bagian kecil dashboard, yaitu bagian judul dashboard, legend dashboard, default tahun ajaran, warna icon dan yang terakhir pada bagian informasi tahun ajaran.

Dalam penelitian ini, didapatkan beberapa hal yang dapat dikembangkan untuk penelitian selanjutnya, antara lain:

1. Tahap learnability pada metode Performance metric akan lebih baik dihitung untuk dibandingkan antara hasil penelitian ini dengan pengujian setelah modifikasi.

2. Beberapa saran modifikasi dari responden yang belum dapat diimplementasikan pada dashboard karena keterbatasan waktu antara lain, dropdown chooser tahun ajaran pada halaman detail dan report.

3. Data KRS \& KHS akan lebih baik dilengkapi dalam rentan waktu 5 tahun terakhir, sehingga grafik yang ditampilkan dapat ditampilkan dengan lebih menarik.

\section{UCAPAN TERIMA KASIH}

Dalam menyelesaikan laporan skripsi ini, tidak terlepas dari bantuan dan dukungan yang sepenuhnya diberikan dari berbagai pihak. Oleh karena itu, penulis ingin menyampaikan ucapan terima kasih antara lain kepada orang tua, dosen dan teman-teman yang telah membantu dan menemani dalam proses pengerjaan skripsi.

\section{DAFTAR PUSTAKA}

[1] D. Januarita and T. Dirgahayu, "Pengembangan Dashboard Information System (DIS)," J. INFOTEL - Inform. Telekomun. Elektron. , vol. 7, no. 2, p. 165, 2015.

[2] M. K. Sabariah, I. N. Denis O. W, and D. D. Jatmiko S. "Rekomendasi User Interface Untuk Aplikasi Mobile Seleksi Mahasiswa Baru (Smb) Telkom Menggunakan Metode Goal Directed Design," vol. 2, no. 2, pp. 6656-6664, 2015.

[3] R. R. Rahardian, R. I. Rokhmawati, and K. C. Brata, "Perancangan User Experience Aplikasi Computer Assisted Test ( CAT ) berbasis Website menggunakan Metode Goal-Directed Design pada Badan Kepegawaian Daerah Kabupaten Lumajang,” vol. 3, no. 7, pp. 64866494, 2019.

[4] A. A. Tejamukti, H. M. Az-zahra, and R. I. Rokhmawati, "Pengembangan Antarmuka Website PPPA Daarul Qur' an Malang Dengan Menggunakan Metode Goal Directed Design,” Pengemb. Teknol. Inf. dan Ilmu Komput. , vol. 2, no. 12, pp. 6277-6285, 2018

[5] J. Annett, "Hierarchical Task Analysis," pp. 17-35, 2003.

[6] D. M. Schrepp, "User Experience Questionnaire Handbook," Procedia Comput. Sci. , vol. 27, pp. 491-498, 2014.

[7] Kharis, P. I. Santosa, and W. W. Winarno, "Evaluasi User Experience pada Sistem Informasi Pasar Kerja Menggunakan User Experience Questionnare ( UEQ )," 10th Natl. Conf. Inf. Technol. Electr. Eng. pp. 24-25, 2019.

[8] M. Schrepp, A. Hinderks, and J. Thomaschewski, "Construction of a Benchmark for the User Experience Questionnaire (UEQ),' Int. J. Interact. Multimed. Artif. Intell., vol. 4, no. 4, p. 40, 2017

[9] Knaflic, Cole N, "Storytelling with Data", 2015.

[10] N. H. Rasmussen, M. Bansal, and C. Y. Chen, Business Dashboards: A Visual Catalog for Design and Deployment. 2009.

[11] A. G. Prabawati, "Pengembangan Key Performance Indicator untuk Manajemen Pendidikan Tinggi," 2019. 
[12] J. Sauro and J. R. Lewis, Quantifying the User Experience. USA: Elsevier Inc, 2012.

[13] B. A. Tom Tullis, Measuring the User Experience Collecting, Analyzing, and Presenting Usability Metrics, Second Edi. , vol. 91, no. 5. Elsevier Inc, 2012.

[14] B. A. Tom Tullis, Measuring the User Experience Collecting, Analyzing, and Presenting Usability Metrics, Second Edi., vol. 91, no. 5. Elsevier Inc, 2012.

[15] J. Tidwell, Designing Interfaces, Second Edition, Second Edi. Canada: O'Reilly Media, Inc, 2011.

[16] A. Ahmad, "Perkembangan Teknologi Komunikasi dan Informasi : Akar Revolusi dan Berbagai Standarnya," Mediator, vol. 5, no. 2, pp. 137-149, 2012.

[17] A. J. Nathan and A. Scobell, "How China sees America," Foreign Aff. , vol. 91, no. 5, pp. 1689-1699, 2012

[18] C. Wei and F. Xing, "The comparison of user-centered design and goal-directed design,” 2010 IEEE 11 th Int. Conf. Comput. Ind. Des. Concept. Des. CAID CD'2010, vol. 1, pp. 359-360, 2010.

[19] D. C. Alan Cooper, Robert Reimann, About Face 2. 0: The Essentials of Interaction Design: Alan Cooper and Robert Reimann Published by John Wiley \& Sons, 2003, 576 pp, ISBN 0764526413, vol. 3, no. 3. 2004.

[20] F. C. Saputro, W. Anggraeni, and A. Mukhlason, "Pembuatan Dashboard Berbasis Web Sebagai Sarana Evaluasi Diri Berkala Untuk Persiapan Penilaian Akreditasi Berdasarkan Standar Badan
Akreditasi Nasional Perguruan Tinggi," J. Tek. ITS, vol. 1, no. 1, pp. A397-A402, 2012.

[21] J. Sauro and J. R. Lewis, Quantifying the User Experience. USA: Elsevier Inc, 2012.

[22] M. Prommann and T. Zhang, "Applying hierarchical task analysis method to discovery layer evaluation," Inf. Technol. Libr. , vol. 34, no. 1, pp. 77-105, 2015.

[23] G. Virginia et al., Buku Panduan Akademik Kurikulum 2017. 2017.

[24] E. I. Listyaningsih, R. Delima, and L. D. Krisnawati, "Evaluasi Antarmuka Sistem Informasi Aktivitas Pertanian Menggunakan Pendekatan Uji Usabilitas," 2018.

[25] K. J. Naban, B. Susanto, and G. Virginia, "Pembangunan Data Warehouse untuk Analisis Harga dan Kuantitas Dalam Bisnis Ritel," 2016

[26] Y. Stefan, N. A. Haryono, and A. W. Mahastama, "Penerapan Metode Goal Directed Design untuk Perancangan Sistem Jalur Pesebaran Rempah Nusantara,”2018.

[27] R. A. Subakti, K. A. Nugraha, and D. Sebastian, "Perancangan Dashboard untuk Website Mashup Sosial media Menggunakan Metode Goal Directed Design," 2019.

[28] P. J. Kusuma, I. D. E. K. R, and Restyandito, "Perancangan Ulang Website Zalora Indonesia Menggunakan Metode Goal-Directed Design dan Aspek Quim,” 2018.

[29] T. Green, J. Cao, and M. Bowers, The Guide to Interactive Wireframing. UXPin Inc, 2015 